\title{
Energy Consumption and Expenditure Projections by Income Quintile on the Basis of the Annual Energy Outlook 1997 Forecast
}

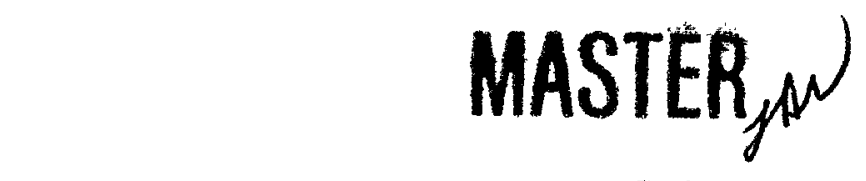

DIBTPIBUTION OF THIS DOCUMENT INLMITED

Decision and Information

Sciences Division

Argonne National Laboratory

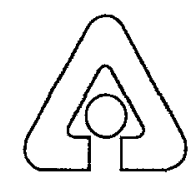

Operated by The University of Chicago,

under Contract W-31-109-Eng-38, for the

United States Department of Energy 


\section{Argonne National Laboratory}

Argonne National Laboratory, with facilities in the states of llinois and ldaho, is owned by the United States Government, and operated by the University of Chicago under the provisions of a contract with the Department of Energy.

This technical memo is a product of Argonne's Decision and Information Sciences (DIS) Division. For information on the division's sclentific and engineering activities, contact:

Director, Decision and Information

Sciences Division

Argonne National Laboratory

Argonne, illinois 60439-4832

Telephone (630) 252-5464

http://www.dis.anl.gov

Presented in this technical memo are preliminary results of ongoing work or work that is more limited in scope and depth than that described in formal reports issued by the DIS Division.

Publishing support services were provided by Argonne's Information and Publishing Division (for more information, see IPD's home page: http://www.ipd.anl.gov/)

\section{Disclaimer}

This report was prepared as an account of work sponsored by an agency of the United States Government. Neither the United States Government nor any agency thereof, nor any of their employees, makes any warranty, express or implied, or assumes any legal liability or responsibility for the accuracy, completeness, or usefulness of any information, apparatus, product, or process disclosed, or represents that its use would not infringe privately owned rights. Reference herein to any specific commercial product, process, or service by trade name, trademark; manufacturer, or otherwise, does not necessarily constitute or imply its endorsement, recommendation, or favoring by the United States Government or any agency thereof. The vlews and opinions of authors expressed herein do not necessarily state or reflect those of the United States Government or any agency thereof.

Reproduced directly from the best available copy.

Available to DOE and DOE contractors from the Office of Sclentific and Technical Information, P.O. Box 62, Oak Ridge, TN 37831; prices available from (423) 576-8401.

Available to the public from the National Technical Information Service, U.S. Department of Commerce, 5285 Port Royal Road, Springfield, VA 22161. 


\section{DISCLAIMER}

Portions of this document may be illegible electronic image products. Images are produced from the best available original document. 


\section{Energy Consumption and Expenditure Projections by Income Quintile on the Basis of the Annual Energy Outlook 1997 Forecast}

by D.A. Poyer and T. Allison

Decision and Information Sciences Division,

Argonne National Laboratory, 9700 South Cass Avenue, Argonne, Illinois 60439

March 1998

Work sponsored by U.S. Department of Energy, Office of Economic Impact and Diversity 
This report is printed on recycled paper. 


\section{CONTENTS}

ABSTRACT

SUMMARY

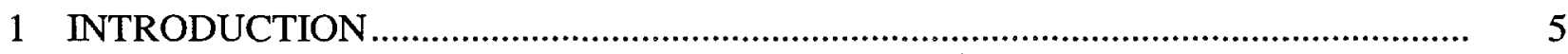

2 ENERGY CONSUMPTION AND INCOME CLASS ............................................ 6

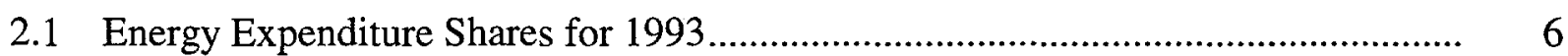

2.2 Home Type and Energy Consumption ............................................................ 9

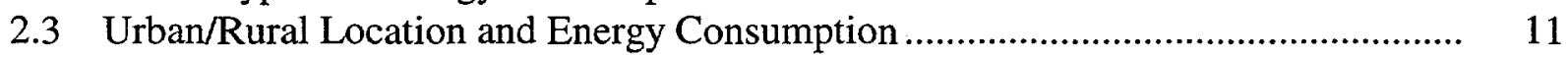

2.4 Geographic Location and Energy Consumption ................................................ 14

2.5 Housing Vintage and Energy Consumption ................................................. 17

3 PROJECTIONS FOR ENERGY CONSUMPTION AND EXPENDITURES................. 23

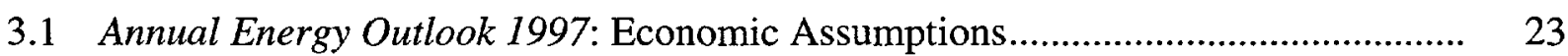

3.2 Electricity Consumption and Expenditures................................................... 26

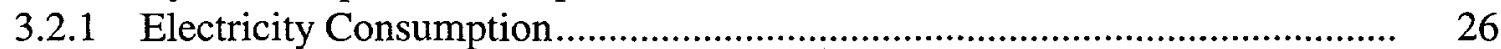

3.2.2 Electricity Expenditures ................................................................. 28

3.3 Natural Gas Consumption and Expenditures ................................................ 28

3.3.1 Natural Gas Consumption .................................................................. 28

3.3.2 Natural Gas Expenditures................................................................. $\quad 30$

3.4 Distillate Fuel Consumption and Expenditures................................................. 31

3.4.1 Distillate Fuel Consumption .............................................................. 31

3.4.2 Distillate Fuel Expenditures ............................................................... 33

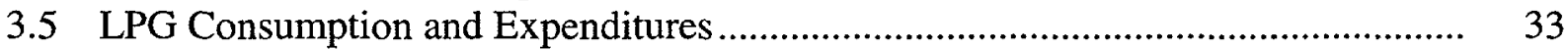

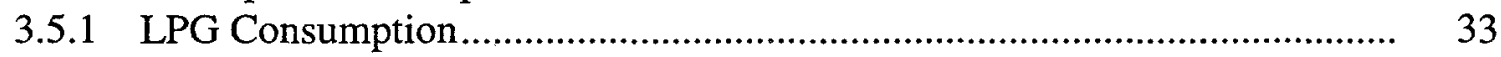

3.5.2 LPG Expenditures .......................................................................... 36

3.6 Household Energy Expenditures and Income Share ...................................... 37

3.6.1 Energy Expenditures ............................................................................. 37

3.6.2 Energy Expenditure Income Share .................................................... 38

3.6.3 Energy Expenditure Composition ..................................................... 38

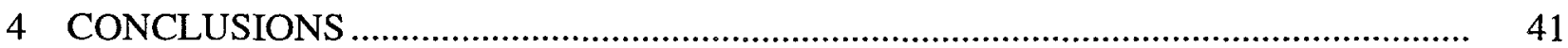

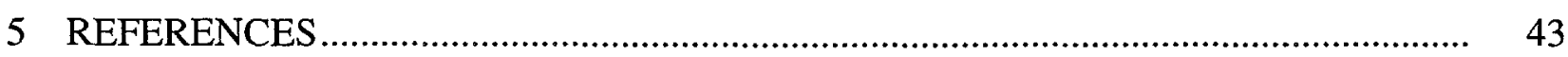




\section{FIGURES}

1 Average Household Energy Expenditure Shares for the First Income Quintile for 1993

2 Average Household Energy Expenditure Shares for the Second Income Quintile for 1993

3 Average Household Energy Expenditure Shares for the Third Income Quintile for 1993

4 Average Household Energy Expenditure Shares for the Fourth Income Quintile for 1993

5 Average Household Energy Expenditure Shares for the Fifth Income Quintile for 1993

6 Average Energy Consumption by Home Type and Fuel Source 10

$7 \quad$ Average Energy Expenditures by Home Type and Fuel Source …..................................... 10

8 Average Energy Consumption by Locality and Source for 1993 ........................................... 13

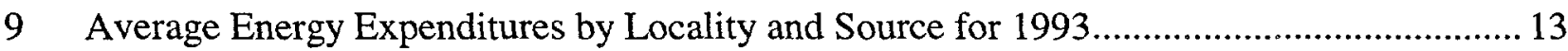

10 Average Energy Consumption by Region and Source for 1993 …....................................... 15

11 Average Energy Expenditures by Region and Source for 1993 .......................................... 16

12 Percentage of Households by Socioeconomic Group and Housing Vintage for 1993

13 Annual Percentage Change in Real Energy Prices for 1993 through 2015 .25

14 Annual Percentage Change in Real Household Income for 1993 through 2015 26

15 Electricity Consumption by Income Quintile for 1993, 2000, and 2015 ............................22

16 Aggregate Electricity Consumption Shares by Income Quintile for 1993 27

17 Aggregate Electricity Consumption Shares by Income Quintile for 2015 .............................2 28

18 Electricity Expenditures by Income Quintile for 1993, 2000, and 2015 29 


\section{FIGURES (Cont.)}

19 Natural Gas Consumption by Income Quintile for 1993, 2000, and 2015 29

20 Aggregate Natural Gas Consumption Shares by Income Quintile for 1993 and 2015 30

21 Natural Gas Expenditures by Income Quintile for 1993, 2000, and 2015 .......................... 31

22 Distillate Fuel Consumption by Income Quintile for 1993, 2000, and 2015 ......................... 32

23 Aggregate Distillate Fuel Consumption Shares by Income Quintile for 1993 ....................... 32

24 Aggregate Distillate Fuel Consumption Shares by Income Quintile for 2015 …....................33

25 Distillate Fuel Expenditures by Income Quintile for 1993, 2000, and 2015....................... 34

26 LPG Consumption by Income Quintile for 1993, 2000, and 2015...................................... 34

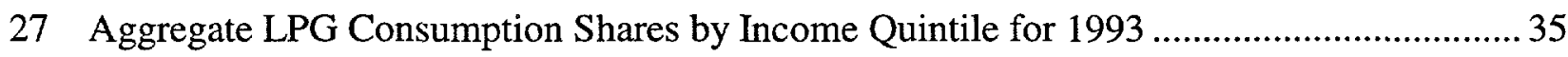

28 Aggregate LPG Consumption Shares by Income Quintile for 2015 ...................................... 35

29 LPG Expenditures by Income Quintile for 1993, 2000, and 2015 ...................................... 36

30 Energy Expenditures by Income Quintile for 1993, 2000, and 2015 .................................... 37

31 Energy Expenditure Share of Income by Income Quintile for 1993, 2000, and $2015 \ldots \ldots \ldots . . .38$

32 Fuel and Electricity Shares of Energy Expenditures by Income Quintile for 1993................ 39

33 Fuel and Electricity Shares of Energy Expenditures by Income Quintile for 2015............... 39

\section{TABLES}

1 Residential Energy Consumption by Income Quintile and Energy Source for 1993

2 Residential Energy Expenditures by Income Quintile and Energy Source for 1993 


\section{TABLES (Cont.)}

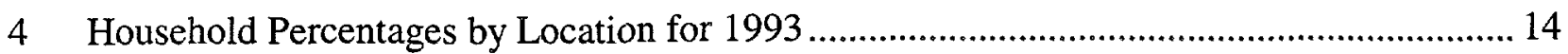

$5 \quad$ Average Household Energy Consumption by Energy Source and Census Region for 1993

6 Average Household Energy Expenditures by Energy Source and Census Region for 1993

7 Household Percentages by Census Region for 1993

8 Average Household Energy Consumption by Energy Source and Housing Vintage for 1993

9 Average Household Energy Expenditures by Energy Source and Housing Vintage for 1993

10 Household Percentages by Housing Vintage and Socioeconomic Group for 1993

11 Marginal Energy Expenditure Shares by Income and Population Class 24 


\section{ACKNOWLEDGMENTS}

We would like to extend special thanks to Georgia Johnson, of the U.S. Department of Energy (DOE), Office of Economic Impact and Diversity, for her continued support of research into patterns of energy use among various population groups. We also thank Steven Wade and John Cymbalsky of DOE's Energy Information Administration, Office of Integrated Analysis and Forecasting, who have been of great assistance in the development of data used to support this analysis. 


\title{
ENERGY CONSUMPTION AND EXPENDITURE PROJECTIONS BY INCOME QUINTILE ON THE BASIS OF THE ANNUAL ENERGY OUTLOOK 1997 FORECAST
}

by

\author{
D.A. Poyer and T. Allison
}

\begin{abstract}
This report presents an analysis of the relative impacts of the base-case scenario used in the Annual Energy Outlook 1997, published by the U.S. Department of Energy, Energy Information Administration, on income quintile groups. Projected energy consumption and expenditures, and projected energy expenditures as a share of income, for the period 1993 to 2015 are reported. Projected consumption of electricity, natural gas, distillate fuel, and liquefied petroleum gas over this period is also reported for each income group.
\end{abstract}

\section{SUMMARY}

This study provides a disaggregated analysis by income class of the Annual Energy Outlook 1997 forecast. Energy consumption and expenditure estimates and forecasts from 1993 through 2015 are provided for five household income quintile groups. The analysis uses the Socio-Economic Research and Analysis Program's Distributive Impact and Assessment Model, an econometric model that uses population-specific energy demand systems. These energy demand systems were estimated from a sequence of Residential Energy Consumption Surveys produced by the U.S. Department of Energy's Energy Information Administration.

Projections show that residential energy use will shift substantially to electricity from distillate fuel and natural gas. This shift will occur disproportionately within the middle income quintile. The middle income quintile is expected to have the largest relative change in residential patterns of energy use. Some highlights of the forecast follow:

- Electricity

- Of the major sources of energy for residential use, only average household electricity consumption will increase for each income group. 
- The increase in average household electricity consumption will be the highest for the third and fourth quintile income groups, growing at an annual rate of slightly more than $0.6 \%$.

- Because of the decreased cost of electricity, the average cost of electricity per household will decrease for each income group, despite the projected rise in electricity consumption.

- Natural Gas

- Natural gas consumption will decrease slowly between 1993 and 2015 for each income group. The decrease will occur somewhat faster for the fourth and fifth quintile income groups.

- The cost of natural gas will decline for each income group, but at a slightly higher rate for the fourth and fifth quintile groups.

- Distillate Fuel

- The use of distillate fuel will decline dramatically. For example, distillate consumption for the average household will decline by $40 \%$ between 1993 and 2015.

- The decrease in distillate fuel consumption will be largest for the middle income quintile group, where it will decline by 50\% from 1993 through 2015.

- The cost of distillate fuel for the average household will decline over the entire forecast period. The price decline will be largest for the middle income quintile group.

- Liquefied Petroleum Gas (LPG)

- The average household consumption of LPG will fall for each income group, except for the fourth income quintile.

- The projected change in average LPG expenditures will vary across income class. It will increase for the second and fourth income quintile groups and decrease for the other three. LPG expenditures will increase by $14 \%$ for the fourth income quintile group. 
- Energy Expenditures

- Energy expenditures will decline for each income group over the forecast period. The largest declines will be for the lowest and highest income quintiles.

- The electricity share of total energy expenditures will increase dramatically, from $67 \%$ in 1993 to $73 \%$ in 2015 . Likewise, expenditures for electricity will increase for each income class.

- Expenditures for natural gas and fuel oil will fall for each income group. The overall LPG share will increase overall, except for the middle and highest income quintile groups, for which it will decrease.

- During the forecast period, the share of income for energy expenditures will decline. The relative change in energy expenditure share will be approximately the same for each income group - declining by about $30 \%$.

- During the forecast period, the total energy expenditures for electricity will increase for each income quintile. The biggest increase will occur in the middle income quintile, where it will increase from $69 \%$ in 1993 to $75 \%$ in 2015 . 


\section{INTRODUCTION}

Patterns of energy consumption and expenditures differ across population groups because of social circumstances. For various reasons, the factors that influence patterns of energy use often differ among socioeconomic groups. Furthermore, even when various energy-related factors are controlled, differences in patterns of energy use still persist among population groups. ${ }^{1}$ Because of these differences, the effect of changing energy markets on the economic welfare of different groups is probably unequal.

The U.S. Department of Energy (DOE), Office of Economic Impact and Diversity, supports research to develop methodologies and analytical tools that can be used to produce disaggregated forecasts of energy consumption and expenditures. The forecasts are made for various population groups consistent with the DOE/Energy Information Administration (EIA) Annual Energy Outlook (AEO) forecasts. This research is important because patterns of energy consumption and expenditures differ among these various population groups. Statistical analyses of the Residential Energy Consumption Surveys (RECSs) over the last 15 years indicate that patterns of energy consumption generally differ among population groups and income classes. Causes of these variations are the facts that populations are distributed differently over energyrelated variables and that the residential energy demand structure is inconsistent. As a result, these groups have various degrees of vulnerability to changing energy prices. Consequently, these differences are likely to lead to disparate economic outcomes for these groups (Poyer and Williams 1993; Poyer et al. 1997).

In the following sections, information is presented on the distribution of income quintile and socioeconomic groups over important energy-related factors. It becomes apparent that substantial differences exist.

1 Unobserved factors or the quality of data are possible explanations for differences in patterns of energy use, as are "preference" or "cultural" differences among population groups. 


\section{ENERGY CONSUMPTION AND INCOME CLASS}

It is obvious to most people that demographics, location, and way of life are different for households with low and high incomes. What has not been considered is the effects of these differences on the level and patterns of energy use. Total energy consumption and expenditures increase as income increases (i.e., the higher income quintile), as shown in Tables 1 and 2 (DOE 1995a,b). However, patterns of consumption and expenditures for individual sources of residential energy are not as predictable. These data indicate that residential energy is a normal good because its consumption and expenditures increase as income increases.

Consumption and expenditures for electricity and distillate fuel increase with each income quintile, but consumption and expenditures for natural gas and liquefied petroleum gas (LPG) are less predictable. Consumption and expenditures for natural gas increase for each higher income quintile, except for the middle income group. On the other hand, consumption and expenditures for LPG peak in the middle income quintile and fall in the lowest and highest income quintiles (bell-shaped). Income quintiles are numbered 1-5, where quintile 1 represents the lowest income quintile group, and quintile 5 is the highest.

\subsection{ENERGY EXPENDITURE SHARES FOR 1993}

The energy expenditure shares for 1993 are shown for the four major residential energy sources for each income quintile group in Figures 1-5. These figures show a difference in energy expenditure fuel mix between the lower income and higher income groups. The natural gas expenditure share is nearly five percentage points higher for the two lower income groups than for the three higher income quintiles. On the other hand, the electricity expenditure share is about four percentage points lower for the two lower income groups than for the three higher income groups. Note that all sources of energy have been converted to millions of Btu for means of comparison.

Energy consumption and expenditure patterns differ by socioeconomic group (nonHispanic whites and blacks and Hispanics), and these differences tend to prevail even after controlling for income (Poyer and Williams 1993; Poyer et al. 1997). This fact is particularly true for lower income groups; however, some convergence in energy consumption patterns occurs in the higher income groups. These differences are partly explained by differences in household population distribution over energy-related variables. Some important energy-related variables are geographic area of the United States, urban or rural location, number of household members, type of housing, age of housing, and home ownership or rental property. In the following sections, patterns of energy consumption and expenditures are cross-tabulated with these important energy-related variables by income class, race, and Hispanic ethnicity. 
TABLE 1 Residential Energy Consumption by Income Quintile and Energy Source for 1993

\begin{tabular}{|c|c|c|c|c|c|}
\hline \multirow[b]{2}{*}{$\begin{array}{l}\text { Income } \\
\text { Quintile }\end{array}$} & \multicolumn{5}{|c|}{$\begin{array}{l}\text { Annual Average Household Energy Consumption } \\
\left(10^{6} \mathrm{Btu} / \mathrm{yr} \text { per household }\right)\end{array}$} \\
\hline & Electricity & $\begin{array}{c}\text { Natural } \\
\text { Gas }\end{array}$ & Distillate & LPG & Total \\
\hline One & 24.82 & 46.59 & 7.84 & 3.68 & 82.93 \\
\hline Two & 28.57 & 53.47 & 10.14 & 3.86 & 96.04 \\
\hline Three & 35.75 & 49.01 & 11.28 & 5.41 & 101.45 \\
\hline Four & 37.78 & 55.41 & 12.38 & 3.74 & 109.31 \\
\hline Five & 43.11 & 68.48 & 13.95 & 3.07 & 128.61 \\
\hline U.S. avg. & 34.01 & 54.59 & 11.12 & 3.95 & 103.67 \\
\hline
\end{tabular}

Source: DOE (1995a).

TABLE 2 Residential Energy Expenditures by Income Quintile and Energy Source for 1993

\begin{tabular}{lrcccr}
\hline & \multicolumn{5}{c}{$\begin{array}{c}\text { Annual Average Household Energy Expenditures } \\
\text { (\$/yr per household) }\end{array}$} \\
\cline { 2 - 6 } $\begin{array}{l}\text { Income } \\
\text { Quintile }\end{array}$ & Electricity & $\begin{array}{c}\text { Natural } \\
\text { Gas }\end{array}$ & Distillate & LPG & Total \\
\hline One & 621 & 289 & 50 & 39 & 998 \\
Two & 702 & 319 & 65 & 39 & 1,126 \\
Three & 849 & 295 & 73 & 54 & 1,271 \\
Four & 933 & 338 & 81 & 36 & 1,388 \\
Five & 1,088 & 420 & 94 & 30 & 1,632 \\
U.S. avg. & 839 & 332 & 73 & 40 & 1,283 \\
\hline
\end{tabular}

Source: DOE (1995b). 


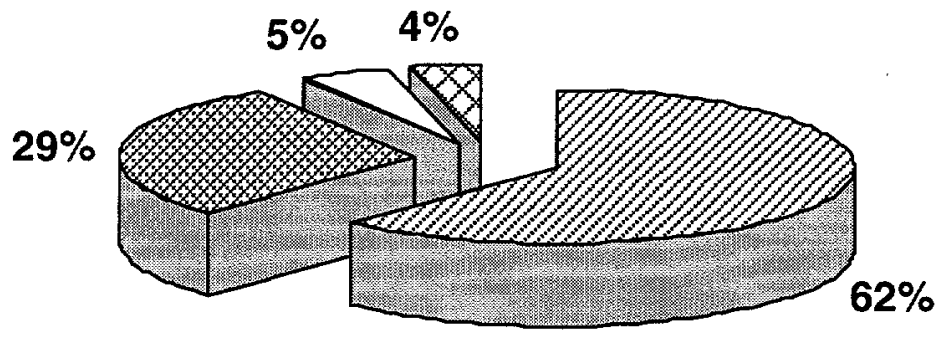

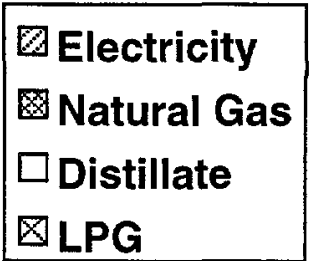

DPA39801

FIGURE 1 Average Household Energy Expenditure Shares for the First Income Quintile for 1993 (Source: DOE 1995a)

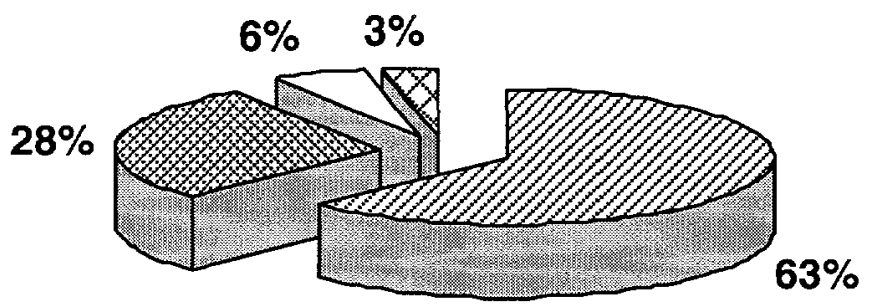

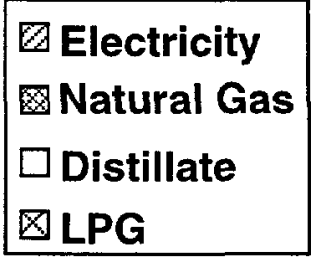

DPA39802

FIGURE 2 Average Household Energy Expenditure Shares for the Second Income Quintile for 1993 (Source: DOE 1995a )

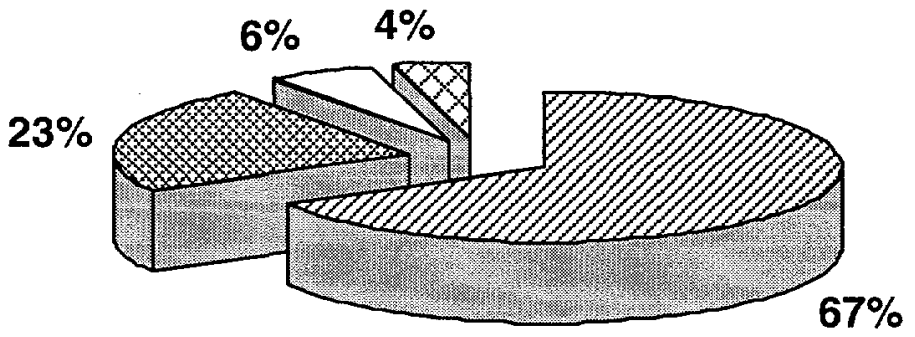

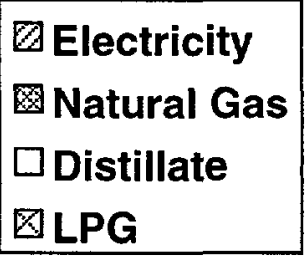

DPA3803

FIGURE 3 Average Household Energy Expenditure Shares for the Third Income Quintile for 1993 (Source: DOE 1995a) 

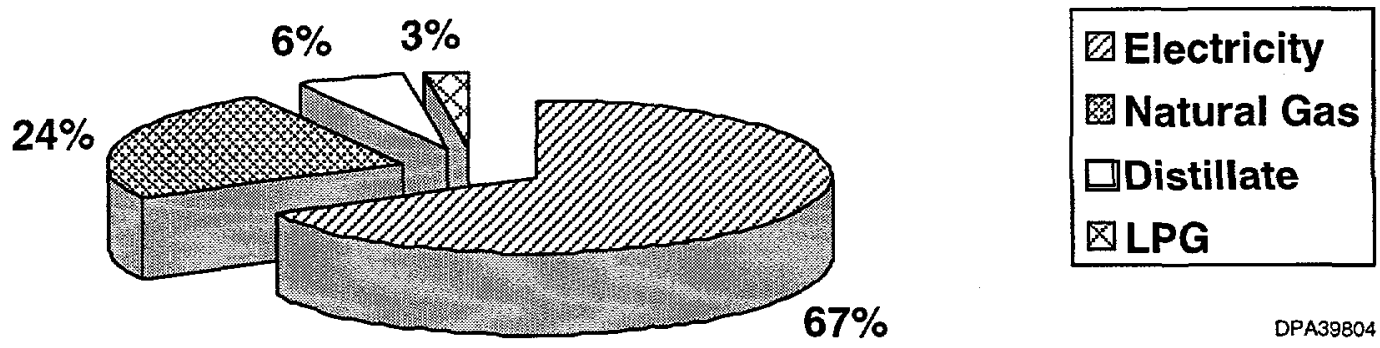

DPA39804

FIGURE 4 Average Household Energy Expenditure Shares for the Fourth Income Quintile for 1993 (Source: DOE 1995a)

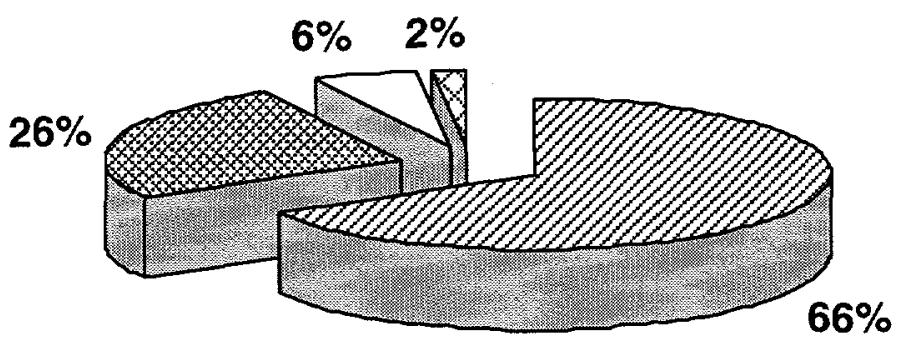

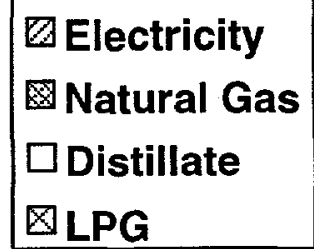

DPA39805

FIGURE 5 Average Household Energy Expenditure Shares for the Fifth Income Quintile for 1993 (Source: DOE 1995a)

\subsection{HOME TYPE AND ENERGY CONSUMPTION}

The relationship between home type and patterns of energy use is recognized explicitly by the EIA in its AEO forecast methodology. Changes in energy use in large part depend on forecasted changes in the composition of housing. Reasons for this relationship are shown in Figures 6 and 7. These figures show the striking relationship between energy consumption/ expenditures and housing type.

Residents in detached single-family homes consume and spend more on energy. The composition of energy use varies widely across home types. The average consumption of electricity is highest in attached single-family homes and mobile homes, and electricity is a much larger fraction of overall residential consumption and expenditures in mobile homes. At the other extreme, electricity consumption and expenditures are both absolutely and relatively lower in small multifamily units. ${ }^{2}$ It is important to distinguish among differences in energy consumption patterns by home type when assessing energy consumption patterns among different income and socioeconomic groups because of differences in the distribution of these groups over home types.

2 Small multifamily housing is defined as multifamily buildings with four or fewer units, and large multifamily housing is defined as multifamily buildings with more than four units. 


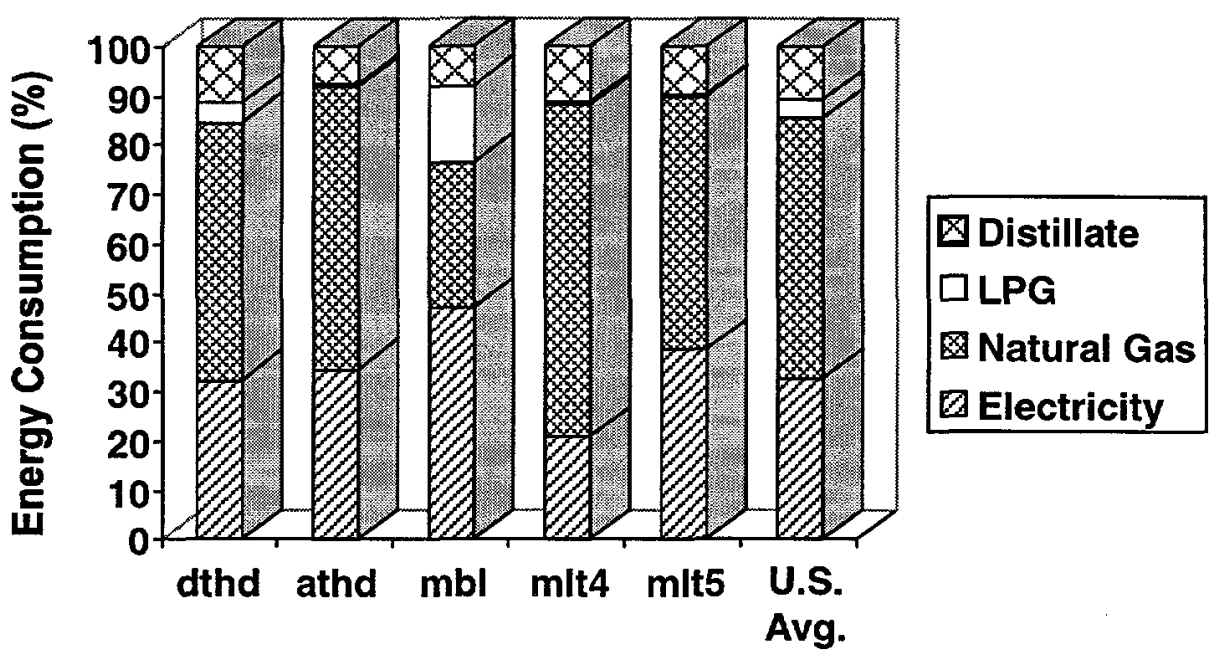

\section{Home Type}

DPA39806

FIGURE 6 Average Energy Consumption by Home Type and Fuel Source (dthd = detached single-family home; athd = attached single-family home; $\mathrm{mbl}=$ mobile home; $\mathrm{mlt} 4$ = small multifamily [ $\leq 4]$ home; and mit5 = large multifamily [ $>4]$ home.) (Source: DOE 1995a)

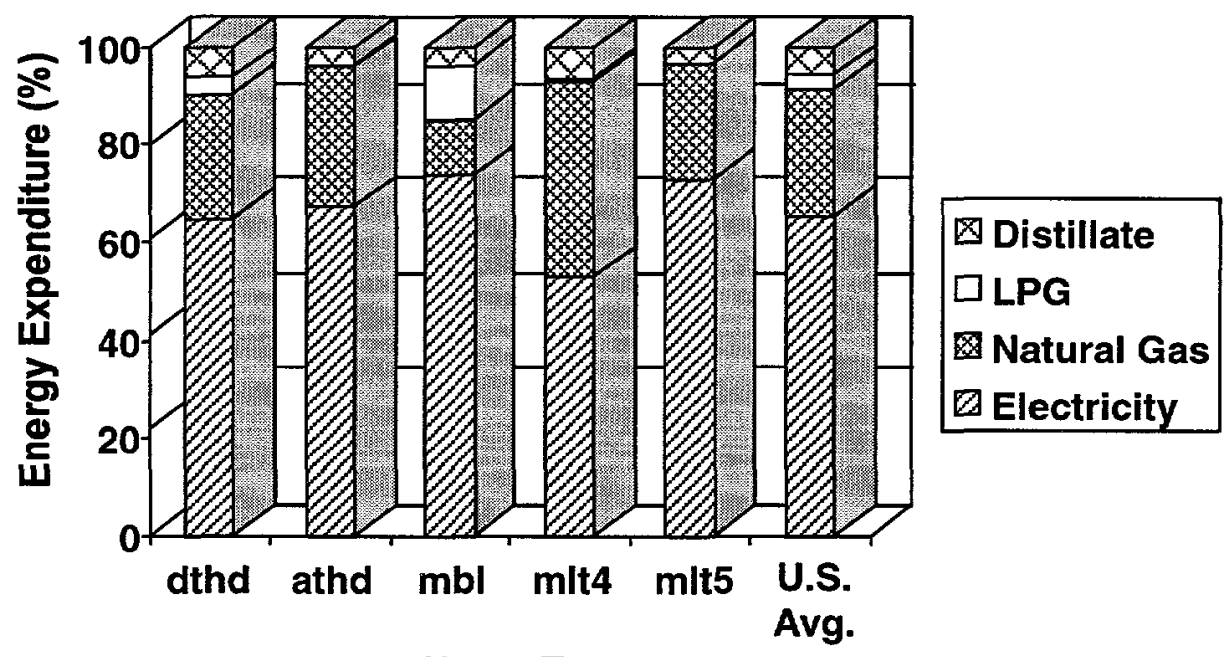

Home Type

DPA39807

FIGURE 7 Average Energy Expenditures by Home Type and Fuel Source (dthd = detached single-family home; athd = attached single-family home; $\mathrm{mbl}=$ mobile home; mlt 4 = small multifamily [ $\leq 4$ ] home; and mlt5 = large multifamily [ $>4]$ home.) (Source: DOE 1995a) 
Table 3 gives the 1993 income and population group distributions by home type. In general, lower-income households tend to live in multifamily housing. More than $40 \%$ of all households in the first income quintile live in multifamily housing, with about $30 \%$ of all first income quintile households living in large multifamily dwellings. On the other hand, only about $11 \%$ of the households in the highest income quintile live in multifamily housing. As a consequence, it is expected that lower income households would consume less energy than higher income households would.

In addition, the 1993 RECS data show a substantial difference in the racial and ethnic home-type distribution of households regardless of income. These data indicate that minority households (non-Hispanic blacks and Hispanics) are more likely to live in multifamily housing than their nonminority counterparts within each income group. This imbalance is probably related to the disproportionate concentration of minorities in central cities.

\subsection{URBAN/RURAL LOCATION AND ENERGY CONSUMPTION}

Figures 8 and 9 give composition of energy consumption and expenditure patterns by urban/rural location in 1993 (DOE 1995a). The difference in the composition of energy use and the level of energy expenditures between urban and rural locations is striking. In rural areas, estimated household energy expenditures are substantially higher than they are in urban areas. Annual household energy expenditures were approximately $40 \%$ higher in rural areas than in urban areas in 1993.

The consumption of electricity, as well as distillate and LPG fuel, is substantially higher in rural communities. Rural areas use a large fraction of these energy sources for space heating, whereas urban areas primarily use natural gas. ${ }^{3}$

Table 4 gives the percentages of households by income and socioeconomic group living in urban and rural areas. Lower income households are more likely to reside in an urban area, and Hispanic and non-Hispanic black households are more likely to live in urban areas regardless of income quintile. The percentage of Hispanics and non-Hispanic blacks living in urban areas is higher than for non-Hispanic whites for each income quintile. The heavy concentration of minority households in urban areas contributes to their relatively higher consumption of natural gas.

3 Natural gas is the primary heating fuel in about $40 \%$ of all rural households and about $60 \%$ of all urban households (DOE 1995a). 
TABLE 3 Household Percentages by Home Type for 1993

\begin{tabular}{|c|c|c|c|c|c|}
\hline \multirow[b]{2}{*}{$\begin{array}{c}\text { Income Quintile } \\
\text { and Socioeconomic } \\
\text { Group }\end{array}$} & \multicolumn{5}{|c|}{ Home Type } \\
\hline & $\begin{array}{l}\text { Detached } \\
\text { Single- } \\
\text { Family }\end{array}$ & $\begin{array}{l}\text { Attached } \\
\text { Single- } \\
\text { Family } \\
\end{array}$ & Mobile Home & $\begin{array}{c}\text { Small } \\
\text { Multifamily } \\
(\leq 4)\end{array}$ & $\begin{array}{c}\text { Large } \\
\text { Multifamily } \\
(>4) \\
\end{array}$ \\
\hline First & 43 & 7 & 8 & 12 & 30 \\
\hline White & 46 & 6 & 10 & 11 & 26 \\
\hline Black & 41 & 9 & 2 & 14 & 35 \\
\hline Hispanic & 31 & 8 & 7 & 16 & 39 \\
\hline Second & 54 & 7 & 9 & 11 & 18 \\
\hline White & 59 & 5 & 10 & 10 & 15 \\
\hline Black & 43 & 13 & 4 & 17 & 23 \\
\hline Hispanic & 41 & 8 & 8 & 18 & 25 \\
\hline Third & 63 & 7 & 7 & 7 & 16 \\
\hline White & 67 & 7 & 7 & 7 & 12 \\
\hline Black & 42 & 11 & 4 & 10 & 33 \\
\hline Hispanic & 41 & 7 & 10 & 6 & 36 \\
\hline Fourth & 69 & 9 & 4 & 7 & 12 \\
\hline White & 72 & 8 & 4 & 6 & 10 \\
\hline Black & 47 & 10 & 2 & 22 & 20 \\
\hline Hispanic & 59 & 9 & 8 & 7 & 18 \\
\hline Fifth & 80 & 8 & 1 & 4 & 7 \\
\hline White & 84 & 7 & 2 & 3 & 5 \\
\hline Black & 53 & 21 & 0 & 9 & 17 \\
\hline Hispanic & 63 & 10 & 1 & 9 & 17 \\
\hline U.S. average & 62 & 8 & 6 & 8 & 17 \\
\hline
\end{tabular}

Source: DOE (1995a). 


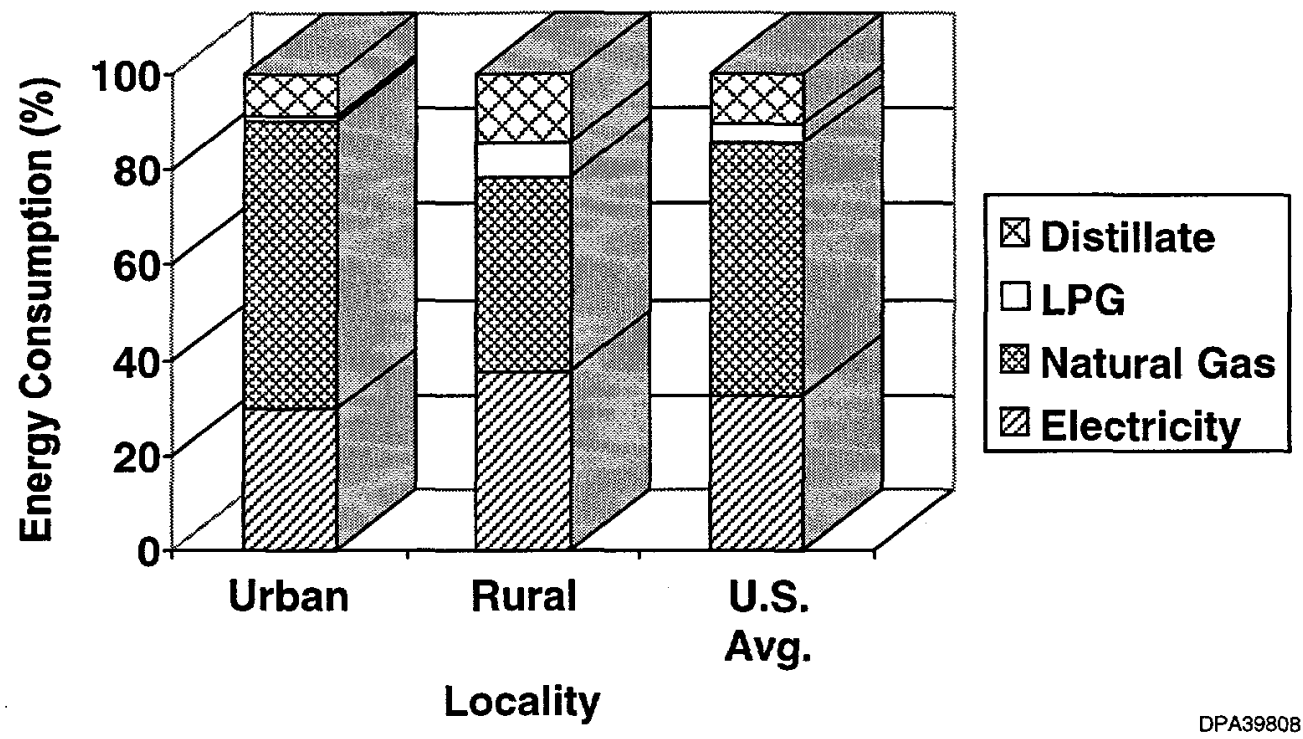

FIGURE 8 Average Energy Consumption by Locality and Source for 1993 (Source: DOE 1995a)

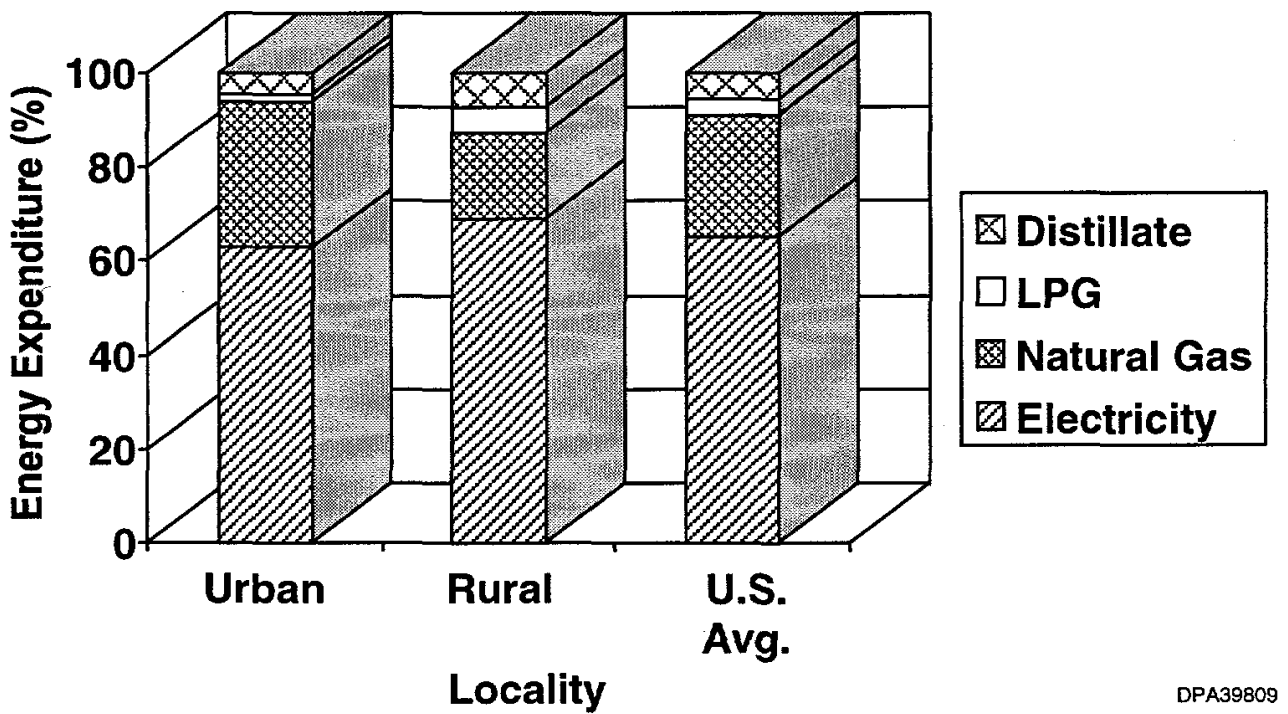

FIGURE 9 Average Energy Expenditures by Locality and Source for 1993 (Source: DOE 1995a) 


\begin{tabular}{|c|c|c|c|c|c|}
\hline \multirow{2}{*}{$\begin{array}{c}\text { Income Quintile } \\
\text { and Socioeconomic } \\
\text { Group }\end{array}$} & \multicolumn{2}{|c|}{ Location $^{a}$} & \multirow{2}{*}{$\begin{array}{c}\text { Income Quintile } \\
\text { and Socioeconomic } \\
\text { Group }\end{array}$} & \multicolumn{2}{|c|}{ Location $^{\mathrm{a}}$} \\
\hline & Urban & Rural & & Urban & Rural \\
\hline First & 74 & 26 & Fourth & 58 & 42 \\
\hline White & 68 & 32 & White & 56 & 44 \\
\hline Black & 86 & 14 & Black & 60 & 40 \\
\hline Hispanic & 84 & 16 & Hispanic & 75 & 25 \\
\hline Second & 68 & 32 & Fifth & 53 & 47 \\
\hline White & 63 & 37 & White & 50 & 50 \\
\hline Black & 85 & 15 & Black & 58 & 42 \\
\hline Hispanic & 80 & 20 & Hispanic & 70 & 30 \\
\hline Third & 60 & 40 & U.S. average & 62 & 38 \\
\hline White & 56 & 44 & White & 58 & 42 \\
\hline Black & 80 & 20 & Black & 78 & 22 \\
\hline Hispanic & 73 & 27 & Hispanic & 78 & 22 \\
\hline
\end{tabular}

${ }^{a}$ For a definition of urban and rural, see DOE (1995a, pp. 309 and 312).

Source: DOE (1995a).

The differences are particularly pronounced among the lower income groups. Lower income minorities are more heavily concentrated in urban areas. As income rises, the urban/rural distribution for non-Hispanic blacks and whites becomes more similar. However, the same is not true for Hispanics; higher income Hispanics are still disproportionately concentrated in urban areas.

\subsection{GEOGRAPHIC LOCATION AND ENERGY CONSUMPTION}

Table 5 gives the average household energy consumption by energy source and Census region for 1993. The composition of energy use by Census region is shown in Figure 10. The level and composition of energy use vary widely by region. Electricity is used more heavily in the South, whereas natural gas is used more heavily in the Midwest, and distillate fuel is used more heavily in the Northeast.

Table 6 gives the average household energy expenditures by energy source and Census region for 1993. The composition of energy expenditures is shown in Figure 11. Overall household energy expenditures are highest in the Northeast and lowest in the West. Average 
TABLE 5 Average Household Energy Consumption by Energy Source and Census Region for 1993

\begin{tabular}{|c|c|c|c|c|c|}
\hline \multirow[b]{2}{*}{$\begin{array}{l}\text { Census } \\
\text { Region }\end{array}$} & \multicolumn{5}{|c|}{$\begin{array}{l}\text { Annual Average Household Energy Consumption } \\
\qquad\left(10^{6} \mathrm{Btu} / \mathrm{yr} \text { per household }\right)\end{array}$} \\
\hline & Electricity & $\begin{array}{c}\text { Natural } \\
\text { Gas }\end{array}$ & $\begin{array}{c}\text { Distillate } \\
\text { Fuel }\end{array}$ & LPG & All \\
\hline Northeast & 24 & 57 & 40 & 1 & 122 \\
\hline Midwest & 32 & 89 & 6 & 8 & 134 \\
\hline South & 45 & 35 & 4 & 4 & 88 \\
\hline West & 28 & 45 & 2 & 2 & 76 \\
\hline U.S. average & 34 & 55 & 11 & 4 & 104 \\
\hline
\end{tabular}

Source: DOE (1995a).

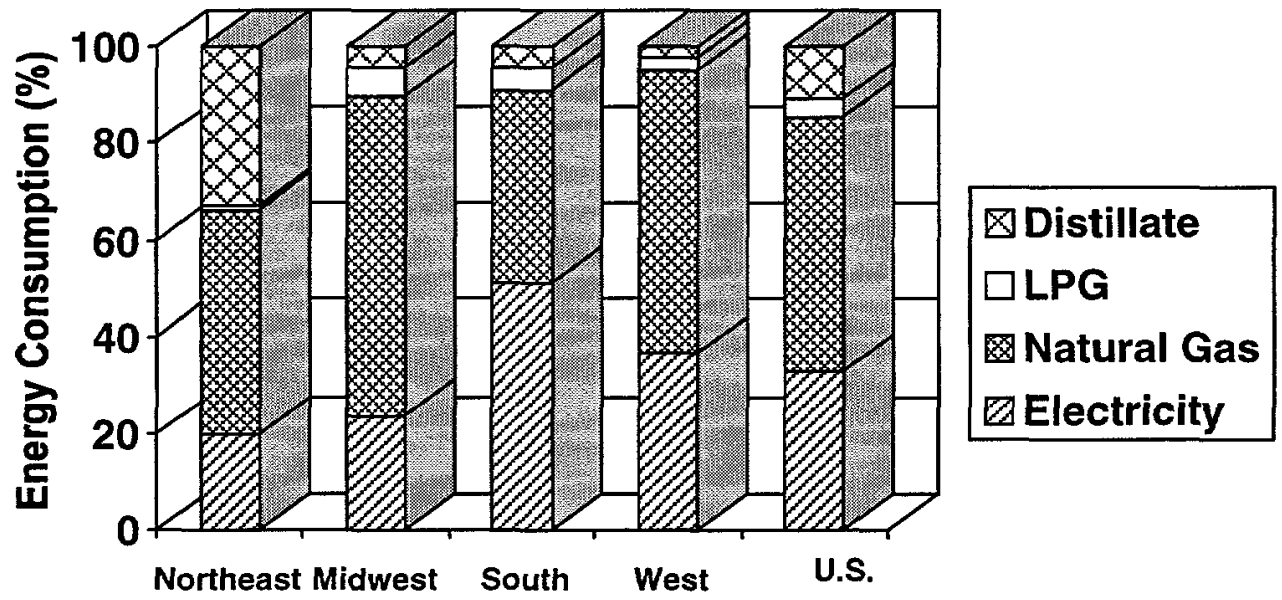

Region

DPA3810

FIGURE 10 Average Energy Consumption by Region and Source for 1993 (Source: DOE 1995a) 
TABLE 6 Average Household Energy Expenditures by Energy Source and Census Region for 1993

\begin{tabular}{|c|c|c|c|c|c|}
\hline \multirow[b]{2}{*}{$\begin{array}{l}\text { Census } \\
\text { Region }\end{array}$} & \multicolumn{5}{|c|}{$\begin{array}{l}\text { Annual Average Household Energy Expenditures } \\
\text { (\$/yr per household) }\end{array}$} \\
\hline & Electricity & $\begin{array}{c}\text { Natural } \\
\text { Gas }\end{array}$ & $\begin{array}{c}\text { Distillate } \\
\text { Fuel }\end{array}$ & LPG & All \\
\hline Northeast & 809 & 441 & 257 & 18 & 1,526 \\
\hline Midwest & 753 & 488 & 36 & 68 & 1,336 \\
\hline South & 1,017 & 216 & 27 & 43 & 1,304 \\
\hline West & 667 & 250 & 12 & 21 & 953 \\
\hline U.S. average & 839 & 332 & 40 & 73 & 1,283 \\
\hline
\end{tabular}

Source: DOE (1995a).

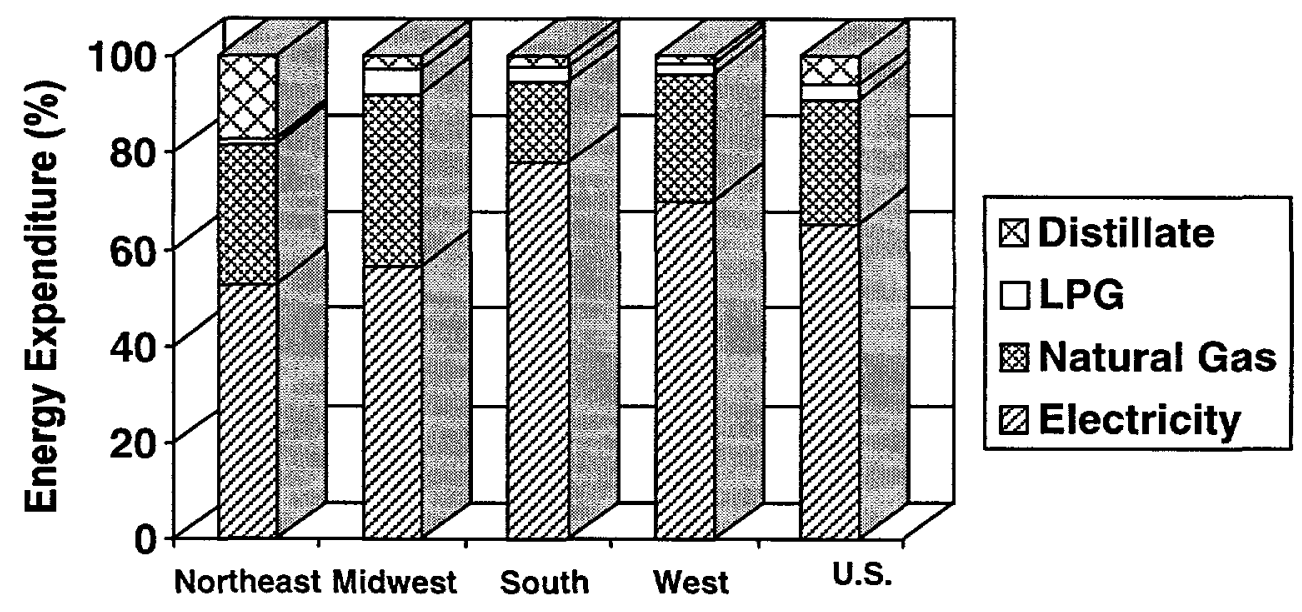

Region

DPA3811

FIGURE 11 Average Energy Expenditures by Region and Source for 1993 (Source: DOE 1995a) 
household energy expenditures in the Northeast are estimated to be more than $60 \%$ higher than expenditures in the West. Household energy expenditures in the Midwest and South are about the same - approximately $\$ 1,300$ per year in 1993.

Electricity expenditures are highest in the South, exceeding electricity expenditures in the Northeast, which has the second highest level of electricity expenditures, by more than $25 \%$. Average household natural gas expenditures are the highest in the Northeast and Midwest. Natural gas expenditures in these regions are nearly twice their level in the South and West. Distillate fuel is consumed almost exclusively in the Northeast, where distillate fuel expenditures dwarf expenditures in any other region.

The Census regions show a marked difference in the relative electricity share of total energy expenditures. For example, while the share of electricity is substantially higher in the South, it is also high in all regions (more than 40\%).

Table 7 gives the 1993 household population distributions by Census region. As expected, the national and non-Hispanic white distributions are very similar, with non-Hispanic whites slightly more concentrated than Hispanics and non-Hispanic blacks in the Northeast and Midwest: The distributions of minority households differ greatly from that of non-Hispanic whites. According to estimates from the 1993 RECS, the concentration of non-Hispanic blacks is heavier in the South; more than $50 \%$ of this population group lives in the South, whereas $33 \%$ of non-Hispanic whites live in that region. Concentrations of Hispanic households are primarily in the West. Approximately $37 \%$ of all Hispanic households are located there, compared with $19 \%$ of all non-Hispanic white households.

\subsection{HOUSING VINTAGE AND ENERGY CONSUMPTION}

Tables 8 and 9 give the average household energy consumption and expenditures, respectively, by housing vintage for 1993. The composition of energy use among homes of various ages differs greatly. For the most part, the consumption of electricity is relatively higher in new homes. However, natural gas consumption increases in homes built after 1989. The use of natural gas and distillate fuel is much less in homes built between 1970 and 1984 than in homes built before $1970 .{ }^{4}$ Estimates show that the 1993 consumption of natural gas and distillate fuel in homes built between 1970 and 1984 is half the estimates of consumption of those fuels in homes built before 1970 .

4 The American economy experienced two large increases in energy prices between 1970 and 1984. The first increase occurred in late 1973 with the outbreak of the Yom Kippur War and the embargo on Arab oil, and the second increase occurred in 1978 with the revolution in Iran and the overthrow of the Shah of Iran. 
TABLE 7 Household Percentages by Census Region for 1993

\begin{tabular}{|c|c|c|c|c|}
\hline \multirow{2}{*}{$\begin{array}{l}\text { Income Quintile and } \\
\text { Socioeconomic Group }\end{array}$} & \multicolumn{4}{|c|}{ Census Region } \\
\hline & Northeast & Midwest & South & West \\
\hline First & 21 & 21 & 40 & 18 \\
\hline White & 21 & 25 & 37 & 18 \\
\hline Black & 17 & 19 & 59 & 5 \\
\hline Hispanic & 31 & 9 & 21 & 40 \\
\hline Second & 17 & 27 & 33 & 23 \\
\hline White & 18 & 31 & 31 & 18 \\
\hline Black & 20 & 22 & 47 & 11 \\
\hline Hispanic & 12 & 11 & 33 & 44 \\
\hline Third & 18 & 26 & 36 & 20 \\
\hline White & 18 & 28 & 35 & 19 \\
\hline Black & 16 & 12 & 55 & 17 \\
\hline Hispanic & 22 & 18 & 31 & 29 \\
\hline Fourth & 22 & 25 & 34 & 19 \\
\hline White & 22 & 27 & 33 & 19 \\
\hline Black & 20 & 26 & 49 & 5 \\
\hline Hispanic & 22 & 13 & 29 & 36 \\
\hline Fifth & 24 & 22 & 32 & 23 \\
\hline White & 24 & 23 & 32 & 21 \\
\hline Black & 27 & 18 & 41 & 14 \\
\hline Hispanic & 24 & 12 & 32 & 32 \\
\hline U.S. average & 20 & 24 & 35 & 21 \\
\hline White & 21 & 27 & 33 & 19 \\
\hline Black & 19 & 19 & 53 & 9 \\
\hline Hispanic & 22 & 12 & 29 & 37 \\
\hline
\end{tabular}

Source: DOE (1995a). 
TABLE 8 Average Household Energy Consumption by Energy Source and Housing Vintage for 1993

\begin{tabular}{|c|c|c|c|c|c|}
\hline \multirow[b]{2}{*}{$\begin{array}{l}\text { Housing } \\
\text { Vintage }\end{array}$} & \multicolumn{5}{|c|}{$\begin{array}{l}\text { Annual Average Household Energy Consumption } \\
\qquad\left(10^{6} \mathrm{Btu} / \mathrm{yr} \text { per household }\right)\end{array}$} \\
\hline & Electricity & $\begin{array}{c}\text { Natural } \\
\text { Gas }\end{array}$ & $\begin{array}{c}\text { Distillate } \\
\text { Fuel }\end{array}$ & LPG & All \\
\hline Before 1940 & 25 & 76 & 22 & 6 & 129 \\
\hline $1940-1969$ & 32 & 63 & 12 & 3 & 110 \\
\hline $1970-1984$ & 40 & 36 & 6 & 3 & 85 \\
\hline 1985-1989 & 42 & 36 & 4 & 4 & 86 \\
\hline After 1989 & 39 & 44 & 4 & 4 & 91 \\
\hline U.S. average & 34 & 55 & 11 & 4 & 104 \\
\hline
\end{tabular}

Source: DOE (1995a).

TABLE 9 Average Household Energy Expenditures by Energy Source and Housing Vintage for 1993

Annual Average Household Energy Expenditures (\$/yr per household)

\begin{tabular}{lccccc}
\cline { 3 - 5 } $\begin{array}{c}\text { Housing } \\
\text { Vintage }\end{array}$ & Electricity & $\begin{array}{c}\text { Natural } \\
\text { Gas }\end{array}$ & $\begin{array}{c}\text { Distillate } \\
\text { Fuel }\end{array}$ & LPG & All \\
\hline & & & & & \\
Before 1940 & 655 & 471 & 140 & 58 & 1,324 \\
$1940-1969$ & 811 & 383 & 78 & 33 & 1,305 \\
$1970-1984$ & 948 & 211 & 39 & 31 & 1,229 \\
$1985-1989$ & 1,005 & 216 & 26 & 47 & 1,294 \\
After 1989 & 899 & 265 & 25 & 45 & 1,234 \\
U.S. average & 839 & 332 & 73 & 40 & 1,283 \\
\hline
\end{tabular}

Source: DOE (1995a). 
Interestingly, the changes in natural gas consumption are exactly the opposite of the movements in electricity consumption. Natural gas consumption in homes built in or before 1989 decreased, whereas electricity consumption increased. Likewise, natural gas consumption increased in homes built after 1989, whereas electricity consumption decreased in homes built during that period. Natural gas consumption in newer homes (built after 1989) is more than 20\% higher than it is in homes built between 1970 and 1989.

Energy expenditures are slightly higher in older homes, but the costs of energy categorized by housing vintage type do not differ. Homes built between 1970 and 1984 show the lowest cost of energy. However, the difference in average household energy expenditures between the highest and lowest housing-vintage category is only $8 \%$, or less than $\$ 8 /$ month.

Table 10 gives the household distribution categorized by housing vintage for income quintile and socioeconomic population group. These data indicate that households with lower incomes typically live in older homes. For example, more than $60 \%$ of first income quintile households live in homes built before 1970, whereas only $48 \%$ of the highest income quintile households live in homes built before 1970. On the other hand, less than $10 \%$ of all first income quintile households live in homes built after 1984, whereas more than $20 \%$ of all fifth income quintile households live in homes built in that period.

These data also indicate differences in the distribution of households by housing vintage among different population categories. Minority households, especially non-Hispanic blacks, are more heavily concentrated in housing built before 1970. These data are also depicted in Figure 12. 
TABLE 10 Household Percentages by Housing Vintage and Socioeconomic Group for 1993

\begin{tabular}{|c|c|c|c|c|c|}
\hline \multirow{2}{*}{$\begin{array}{c}\text { Income Quintile } \\
\text { and Socioeconomic } \\
\text { Group }\end{array}$} & \multicolumn{5}{|c|}{ Housing Vintage } \\
\hline & 1940 & $1940-1969$ & 1970-1984 & $1985-1989$ & After 1989 \\
\hline First & 27 & 36 & 27 & 6 & 3 \\
\hline White & 28 & 33 & 29 & 7 & 3 \\
\hline Black & 27 & 46 & 21 & 4 & 2 \\
\hline Hispanic & 25 & 40 & 24 & 5 & 6 \\
\hline Second & 24 & 39 & 25 & 7 & 4 \\
\hline White & 25 & 38 & 24 & 8 & 4 \\
\hline Black & 29 & 42 & 23 & 6 & 1 \\
\hline Hispanic & 19 & 47 & 23 & 6 & 5 \\
\hline Third & 23 & 36 & 28 & 9 & 5 \\
\hline White & 23 & 36 & 27 & 9 & 5 \\
\hline Black & 20 & 34 & 35 & 9 & 2 \\
\hline Hispanic & 26 & 33 & 31 & 10 & 1 \\
\hline Fourth & 17 & 36 & 26 & 11 & 9 \\
\hline White & 18 & 36 & 25 & 11 & 9 \\
\hline Black & 17 & 37 & 30 & 9 & 7 \\
\hline Hispanic & 13 & 41 & 30 & 11 & 5 \\
\hline Fifth & 14 & 34 & 30 & 12 & 9 \\
\hline White & 14 & 34 & 30 & 13 & 10 \\
\hline Black & 15 & 38 & 34 & 6 & 7 \\
\hline Hispanic & 22 & 28 & 31 & 14 & 6 \\
\hline U.S. average & 21 & 36 & 27 & 9 & 6 \\
\hline White & 21 & 36 & 27 & 10 & 7 \\
\hline Black & 24 & 41 & 26 & 6 & 3 \\
\hline Hispanic & 21 & 39 & 27 & 9 & 5 \\
\hline
\end{tabular}

Source: DOE (1995a). 


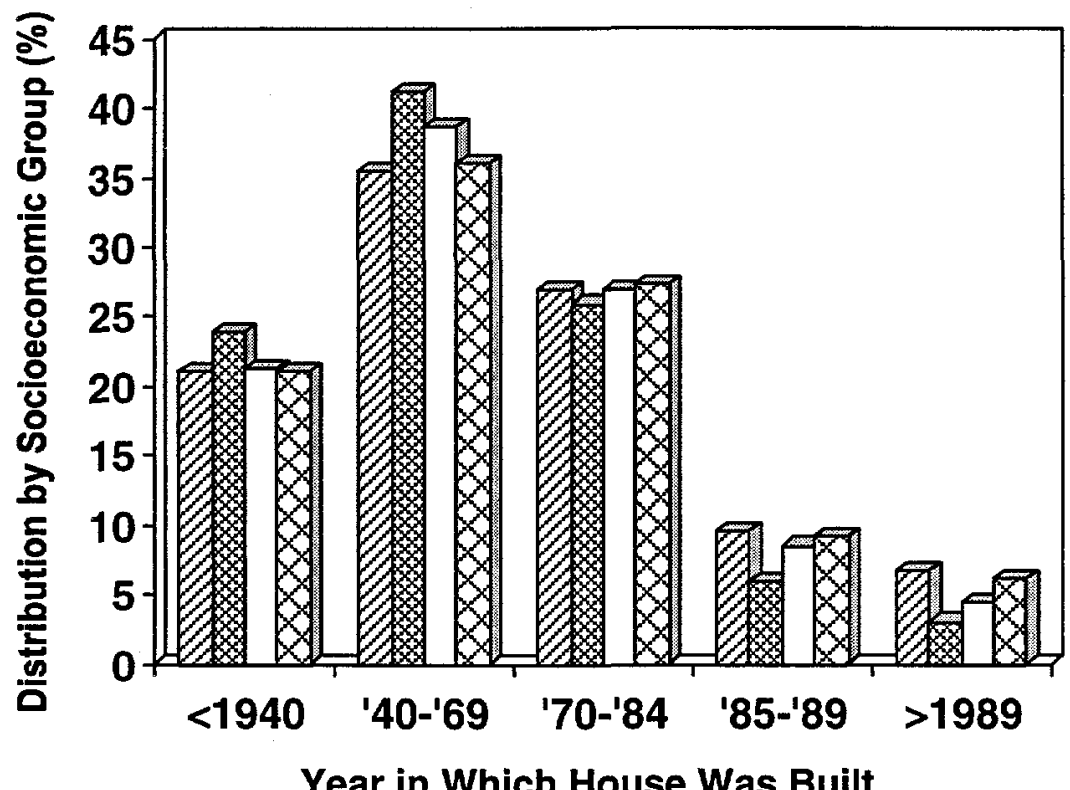

White 圆 Black 口Hispanic QAll

FIGURE 12 Percentage of Households by Socioeconomic Group and Housing Vintage for 1993 (Source: DOE 1995a) 


\section{PROJECTIONS FOR ENERGY CONSUMPTION AND EXPENDITURES}

\subsection{ANNUAL ENERGY OUTLOOK 1997: ECONOMIC ASSUMPTIONS}

The Socio-economic Research and Analysis Program Distributive Impact Assessment Model (DIAM) breaks down the AEO aggregate forecast by income quintile by using household income and energy price forecasts derived from the 1997 AEO reference case (DOE 1996a) and group-specific elasticities.

Energy price and household income forecasts provided by the 1997 AEO and populationspecific energy demand systems 5 are used to estimate energy consumption and expenditures. Relative changes in energy consumption and expenditures are influenced, in part, by differences in the marginal energy expenditure share over different energy sources across population groups. The marginal energy expenditure shares are shown in Table 11 for different income quintile and population groups from 1993 through $2015 .^{6}$

The relative values of the marginal expenditure shares reflect the same relative differences seen in the average energy expenditure shares. Electricity marginal expenditure shares are generally higher for middle income households; natural gas marginal expenditure shares are higher for lower income minority households; and distillate and LPG shares are higher for nonminority households. These data indicate that as household energy expenditures increase, middle income households are more likely to spend a larger percentage of their income on electricity, whereas lower income minority households are more likely to spend a larger percentage of their income on natural gas.

Changes in average real energy prices are shown in Figure 13. They are projected to be modest over the forecast time period. Electricity and natural gas prices are projected to decline slightly, whereas distillate fuel and LPG are projected to increase slightly. These changes are not uniform over the forecast time horizon. For natural gas and electricity, price declines are larger in the near term. Between 1993 and 2000, the price of natural gas is estimated to decrease by about $1.5 \%$ per year, and the price of electricity is expected to decrease by $1 \%$ per year (DOE 1996a, pp. 8-10).

5 These systems are described in Poyer et al. (1997). These models were estimated by income quintile. Changes across population groups (non-Hispanic white and black and Hispanic) were captured with the inclusion of population-group dummy variables.

6 The size of the marginal energy expenditure share parameter is directly related to the size of the demand elasticities. 
TABLE 11 Marginal Energy Expenditure Shares by Income and Population Class

\begin{tabular}{|c|c|c|c|c|}
\hline \multirow{2}{*}{$\begin{array}{c}\text { Income Quintile and } \\
\text { Socioeconomic } \\
\text { Group }\end{array}$} & \multicolumn{4}{|c|}{ Marginal Energy Expenditure Share } \\
\hline & Electricity & $\begin{array}{c}\text { Natural } \\
\text { Gas }\end{array}$ & $\begin{array}{c}\text { Distillate } \\
\text { Fuel }\end{array}$ & LPG \\
\hline \multicolumn{5}{|l|}{ First } \\
\hline White & 0.4678 & 0.2521 & 0.1637 & 0.1164 \\
\hline Black & 0.4030 & 0.4593 & 0.0697 & 0.0680 \\
\hline Hispanic & 0.5315 & 0.2992 & 0.1180 & 0.0513 \\
\hline \multicolumn{5}{|l|}{ Second } \\
\hline White & 0.5033 & 0.2259 & 0.1880 & 0.0828 \\
\hline Black & 0.3549 & 0.5339 & 0.0618 & 0.0494 \\
\hline Hispanic & 0.4906 & 0.2614 & 0.1604 & 0.0876 \\
\hline \multicolumn{5}{|l|}{ Third } \\
\hline White & 0.6276 & 0.1459 & 0.1628 & 0.0637 \\
\hline Black & 0.5909 & 0.2071 & 0.1558 & 0.0462 \\
\hline Hispanic & 0.6441 & 0.1955 & 0.0989 & 0.0615 \\
\hline \multicolumn{5}{|l|}{ Fourth } \\
\hline White & 0.5737 & 0.1873 & 0.1648 & 0.0742 \\
\hline Black & 0.2991 & 0.5222 & 0.1263 & 0.0524 \\
\hline Hispanic & 0.7063 & 0.0952 & 0.1768 & 0.0217 \\
\hline \multicolumn{5}{|l|}{ Fifth } \\
\hline White & 0.5168 & 0.2747 & 0.1267 & 0.0818 \\
\hline Black & 0.5097 & 0.3067 & 0.1589 & 0.0247 \\
\hline Hispanic & 0.4873 & 0.3507 & 0.1197 & 0.0423 \\
\hline \multicolumn{5}{|l|}{ U.S. average } \\
\hline White & 0.5517 & 0.2211 & 0.1504 & 0.0768 \\
\hline Black & 0.4455 & 0.3935 & 0.1083 & 0.0527 \\
\hline Hispanic & 0.5717 & 0.2391 & 0.1323 & 0.0569 \\
\hline
\end{tabular}

Source: DOE (1995a). 


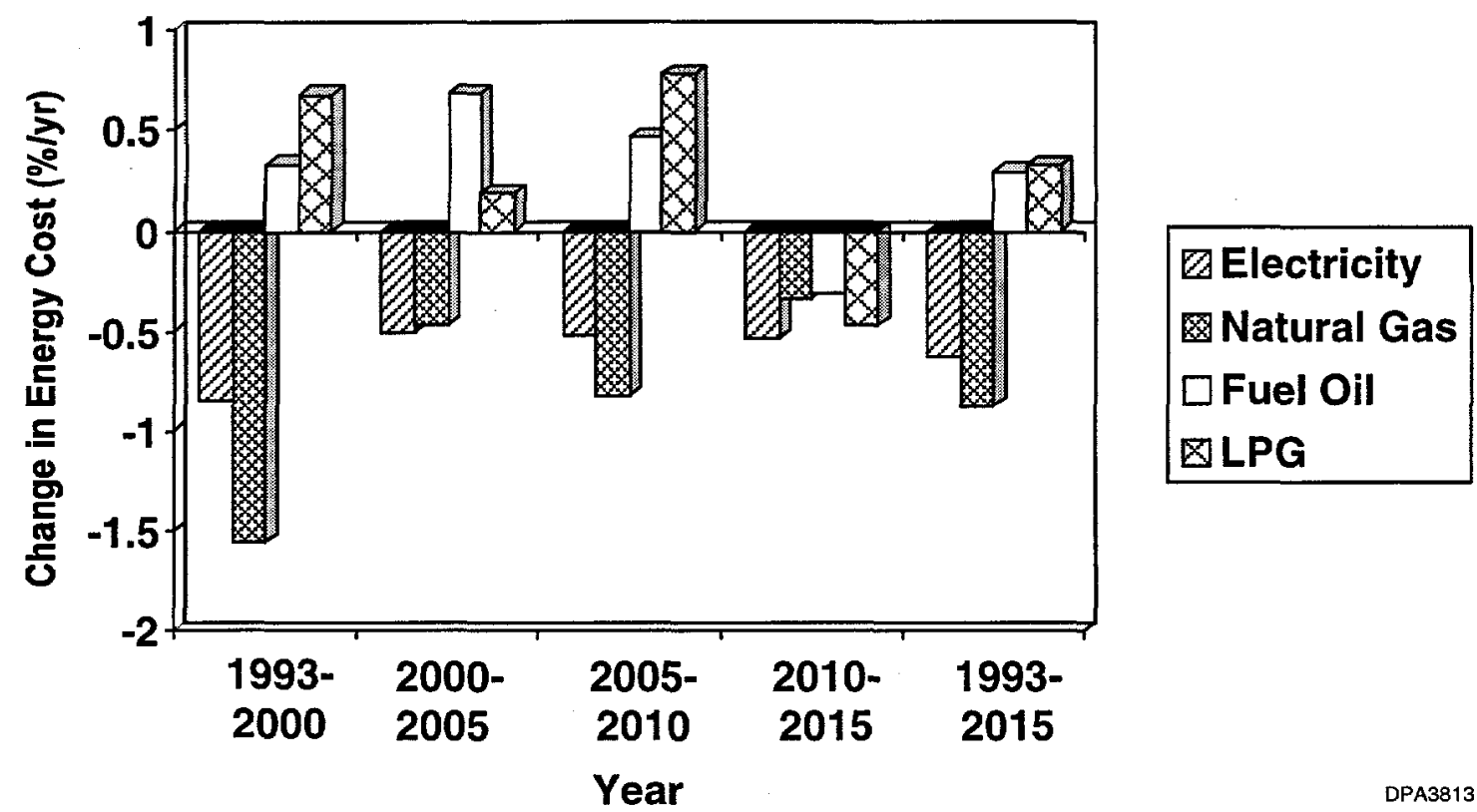

FIGURE 13 Annual Percentage Change in Real Energy Prices for 1993 through 2015 (Source: DOE 1996b)

The projected annual rate of change in real household income is shown in Figure 14. The rate of change is projected to increase over the entire forecast period. The rate of change is projected to decline over the forecast period as a result of the aging of the population. ${ }^{7}$

Taken by itself, and considering the modest changes in energy prices and the strong growth in household income, energy consumption would be expected to grow. However, the EIA incorporates into its forecast technological changes in residential energy consumption that reduce energy use independent of direct market factors.

Sections 3.2.1-3.2.4 give the consumption and expenditure forecast for each of the major residential energy sources by income quintile.

7 The change in real household income was derived from the AEO forecast on real disposable income and household population. 


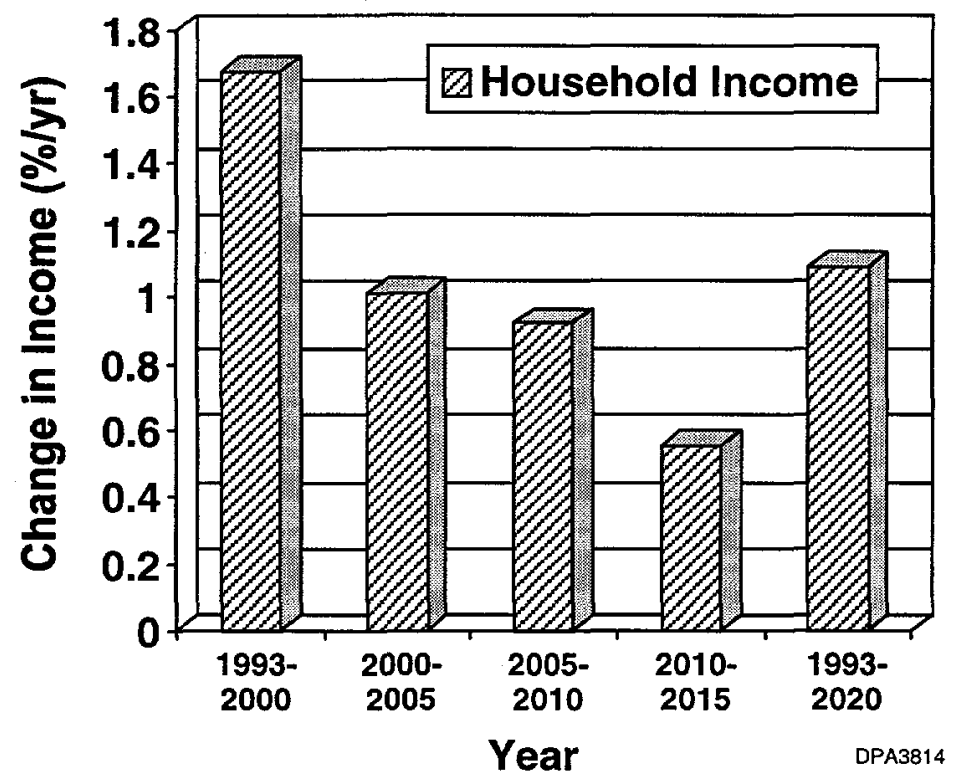

FIGURE 14 Annual Percentage Change in Real Household Income for 1993 through 2015 (Source: DOE 1996b)

\subsection{ELECTRICITY CONSUMPTION AND EXPENDITURES}

\subsubsection{Electricity Consumption}

Forecasts for electricity consumption are shown in Figure 15. Between 1993 and 2015, electricity consumption is projected to increase for each income group. This increase is projected to be the highest for the third and fourth income quintiles and the lowest for the lowest and highest income quintiles. Consumption levels for all households are estimated to increase from 35 million Btu per household per year in 1993 to 40 million Btu in 2015 . Electricity consumption is projected to increase by more than $15 \%$ and $14 \%$ for the third and fourth income quintile groups, respectively, and to increase by slightly more than $10 \%$ for both the lowest and highest income quintile groups. As a result, the share of aggregate electricity for the third and fourth income quintile groups increases between 1993 and 2015, increasing from $21 \%$ to $22 \%$ for the third income group and $22 \%$ to $23 \%$ for the fourth income quintile group. The increase in aggregate electric shares for the third and fourth income quintiles is just offset by the decline in aggregate electric shares for the lowest and highest income quintile groups. The 1993 and 2015 aggregate electric shares are shown in Figures 16 and 17. 


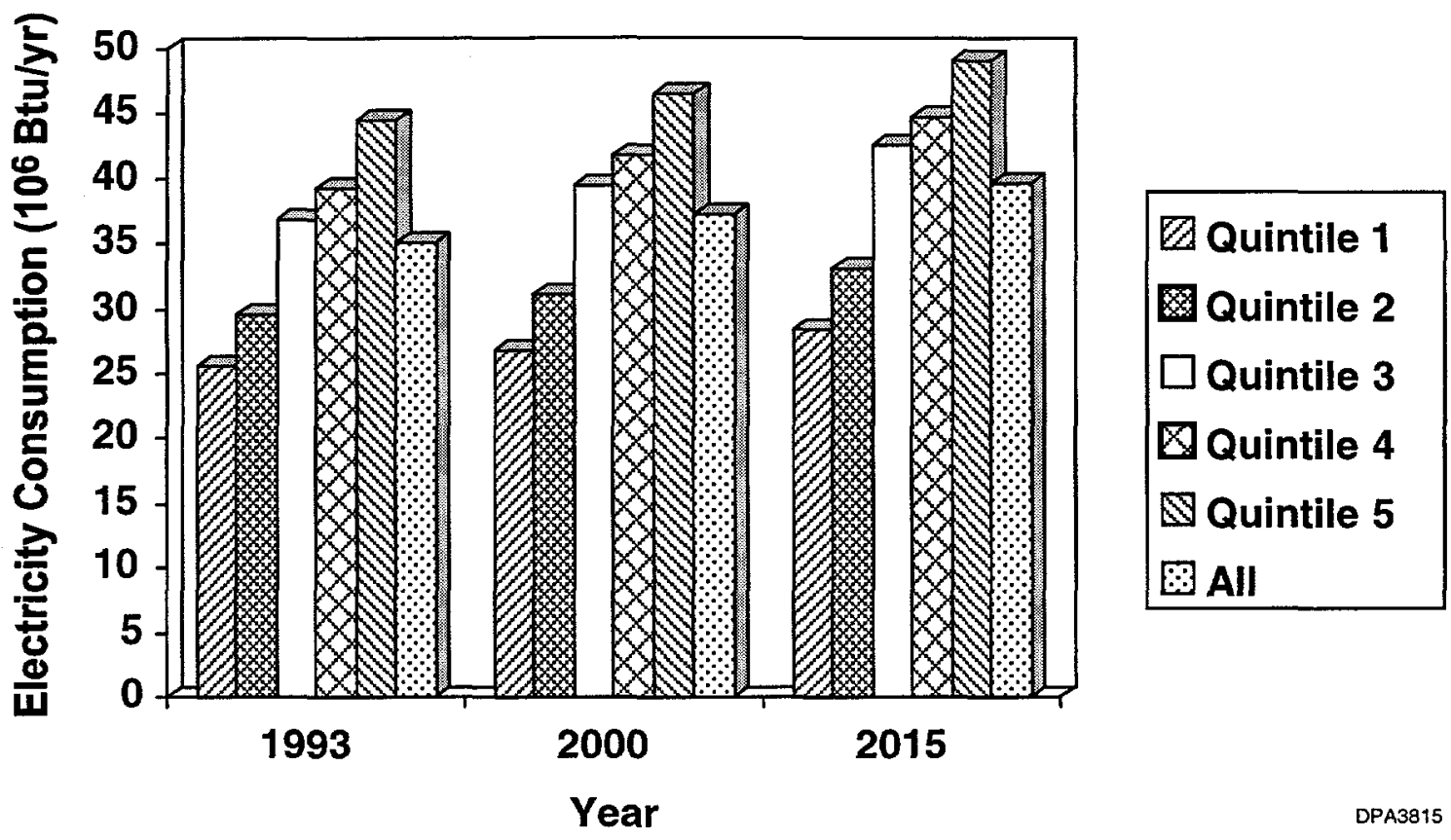

FIGURE 15 Electricity Consumption by Income Quintile for 1993, 2000, and 2015 $\left(10^{6} \mathrm{Btu} / \mathrm{yr}\right)$

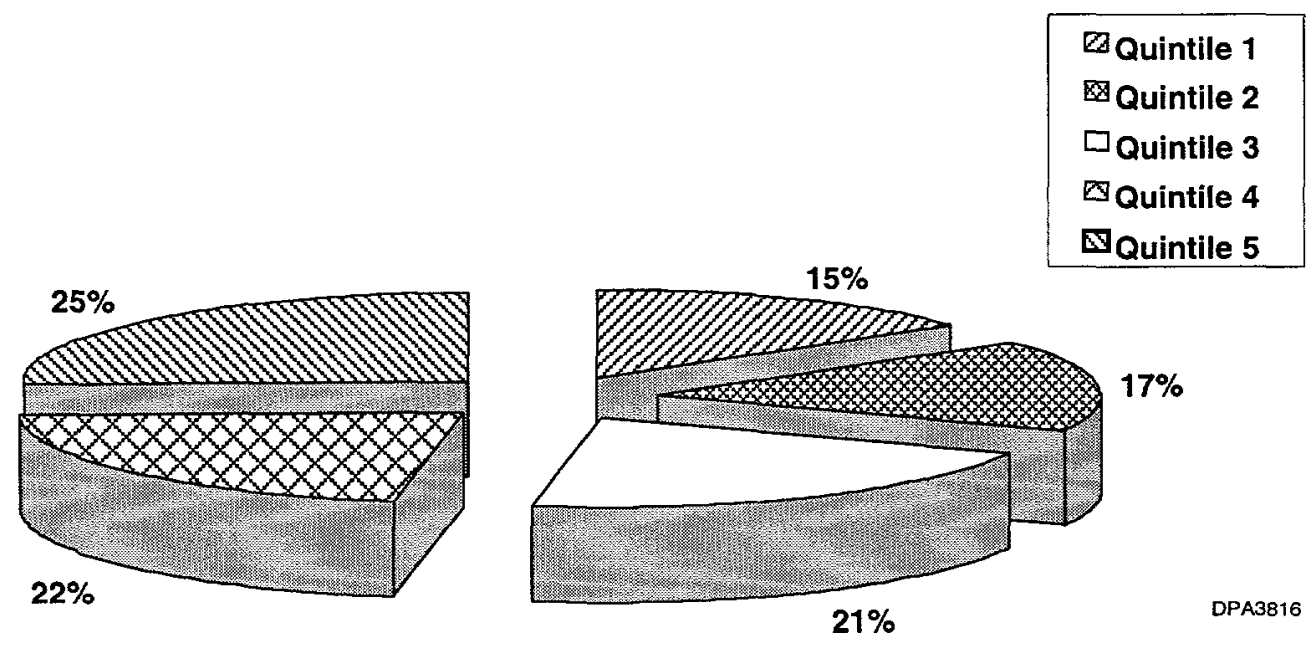

FIGURE 16 Aggregate Electricity Consumption Shares by Income Quintile for 1993 


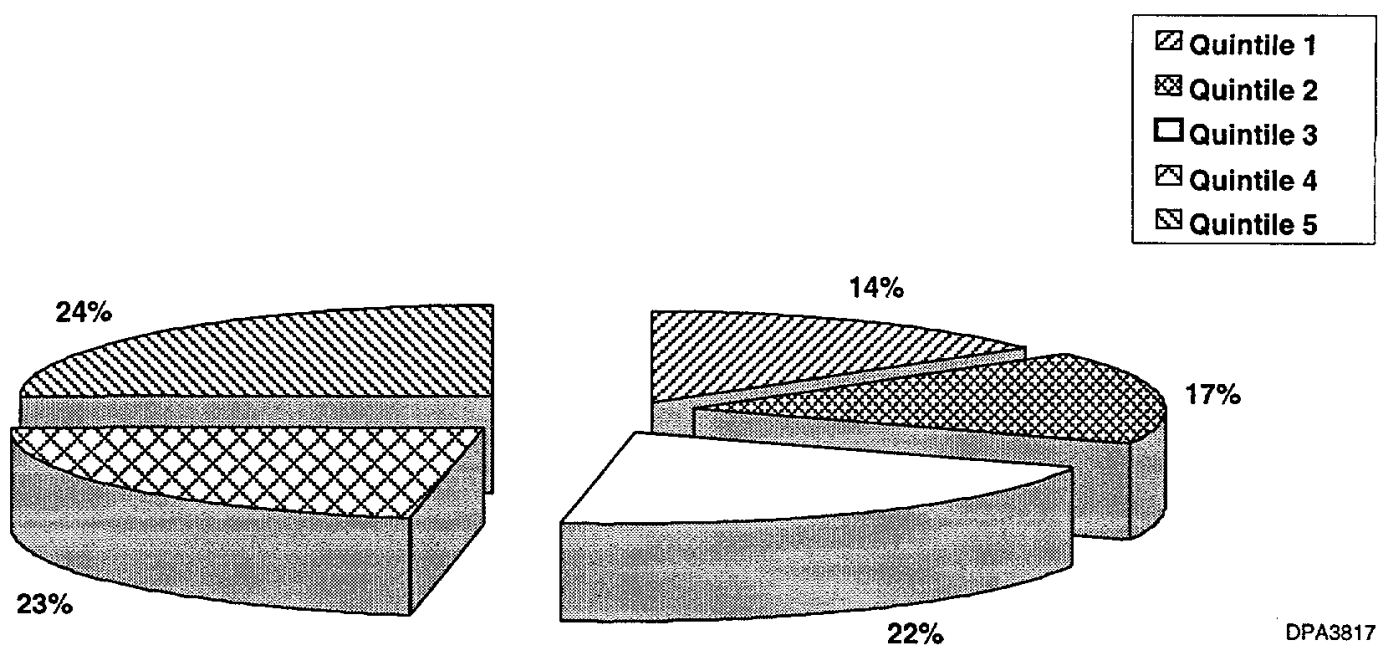

FIGURE 17 Aggregate Electricity Consumption Shares by Income Quintile for 2015

\subsubsection{Electricity Expenditures}

Forecasts for electricity expenditure are shown in Figure 18. Average household expenditures increase as income increases: expenditures for the highest income quintile are more than $70 \%$ higher than those for the lowest income quintile.

Projections show that average household expenditures (in 1993 dollars) on electricity should change slightly between 1993 and 2015, decreasing minimally for each income category, except for the middle income quintile. The average rate of change in electricity expenditures from 1993 through 2015 is projected to decrease by $0.08 \%$ per year. The rates of change for the lowest and highest income quintile groups also are projected to decrease by $0.16 \%$ and $0.19 \%$ per year, respectively, whereas for the middle income quintile, the rate of change is projected to increase by $0.02 \%$ per year.

\subsection{NATURAL GAS CONSUMPTION AND EXPENDITURES}

\subsubsection{Natural Gas Consumption}

Forecasts for natural gas consumption are shown in Figure 19. Except for the middle income quintile, natural gas consumption increases as income increases and decreases between the second and third income quintiles. Natural gas consumption is projected to decline slowly over the forecast time for each income group. However, natural gas consumption is projected to decline slightly faster for the highest income quintile and slower for the second and middleincome quintiles. 


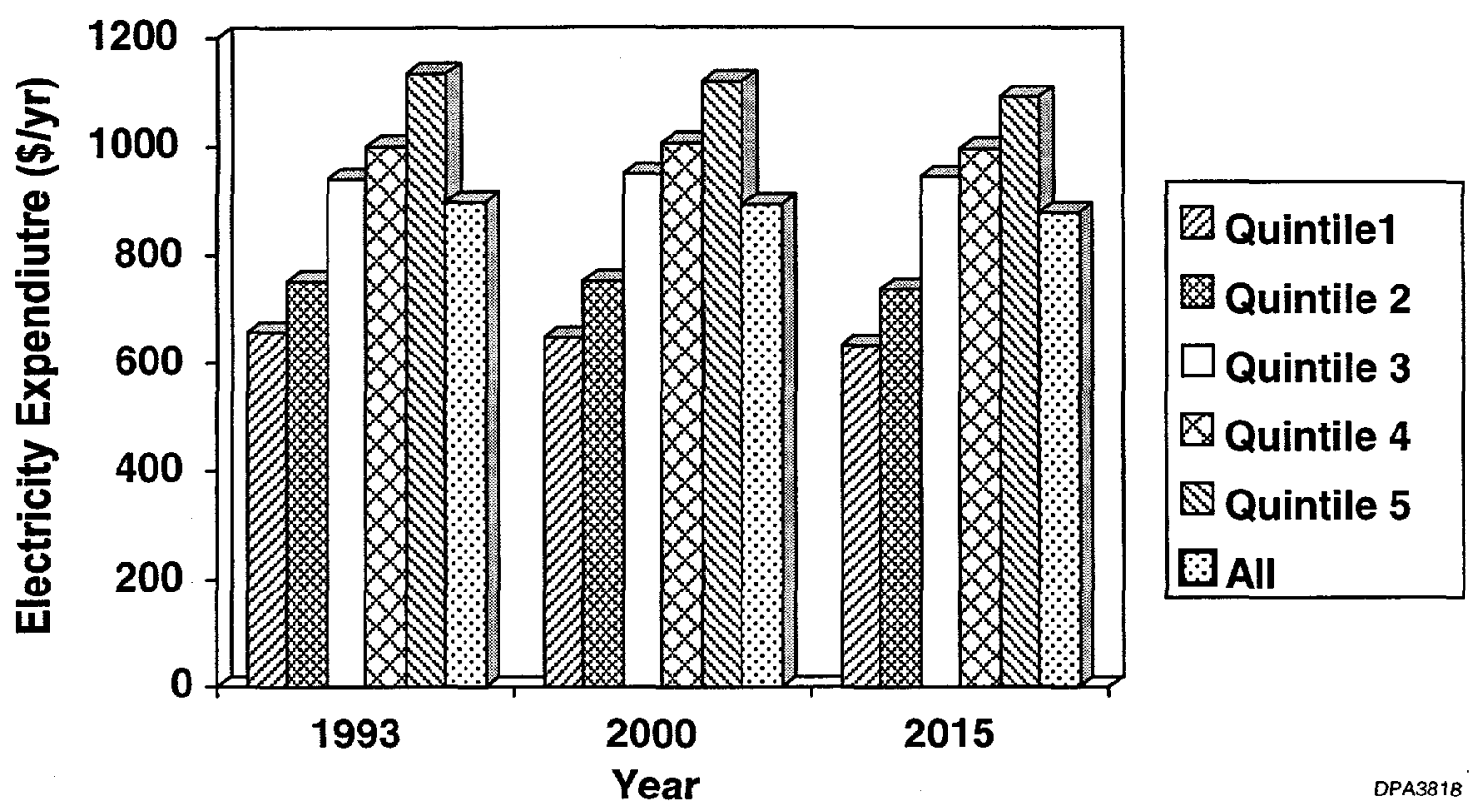

FIGURE 18 Electricity Expenditures by Income Quintile for 1993, 2000, and $2015(\$ / y r)$

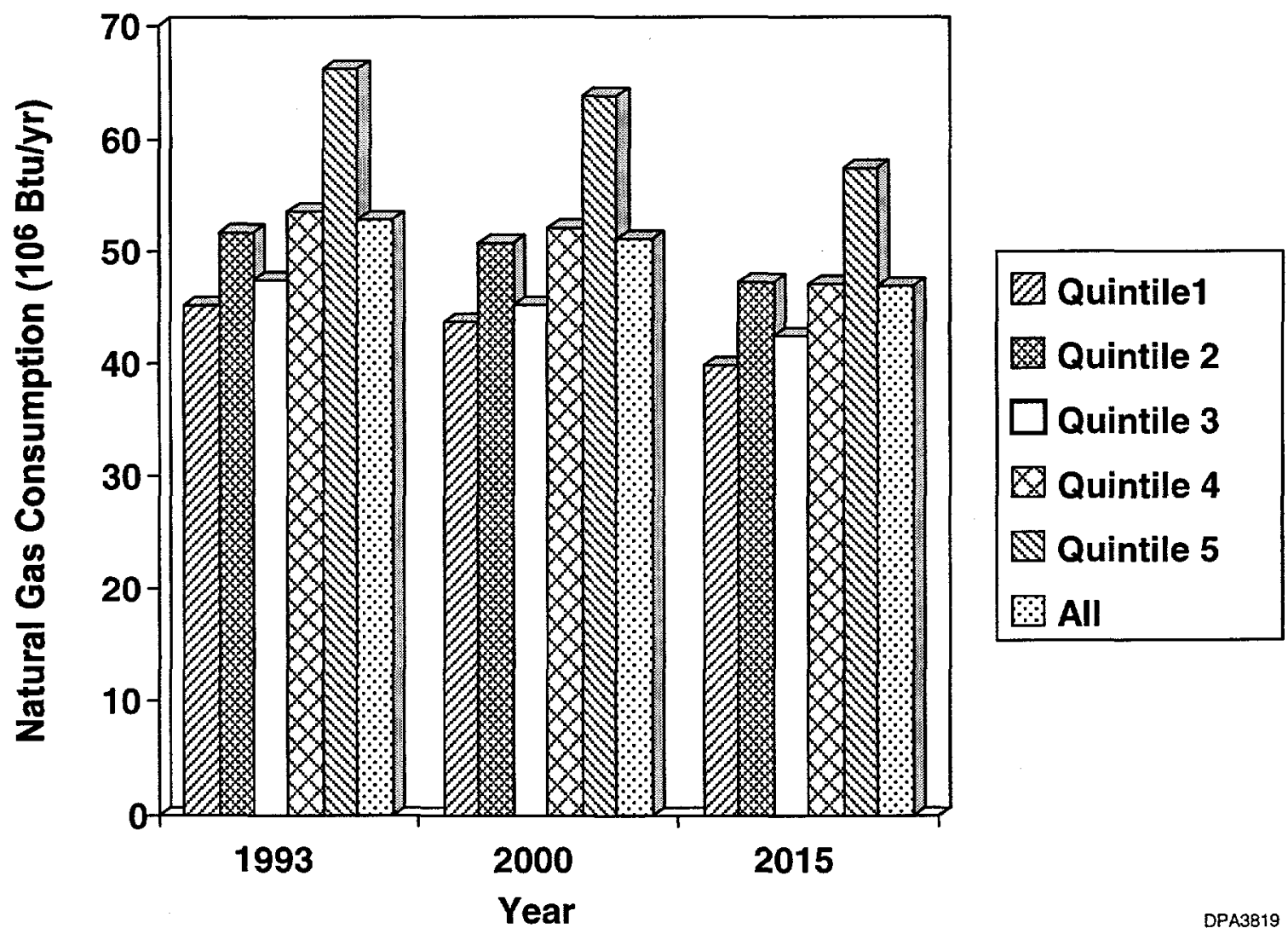

FIGURE 19 Natural Gas Consumption by Income Quintile for 1993, 2000, and 2015 (106 $\mathrm{Btu} / \mathrm{yr}$ per household) 
The effect of changes in natural gas consumption at the household level on income quintile shares is almost imperceptible. The income quintile shares of aggregate natural gas consumption are shown in Figure 20 for 1993. No changes would occur for 2015. The highest income quintile accounts for about 25\% of all natural gas consumption in both 1993 and 2015. The middle income quintile natural gas consumption share (18\%) is smaller than that of the second income quintile (20\%) and approximately equal to that of the lowest income quintile $(17 \%)$. The modest differences in projected natural gas consumption among the different income groups do not affect the relative income quintile shares appreciably and are projected to remain about the same through 2015.

\subsubsection{Natural Gas Expenditures}

Forecasts for natural gas expenditures are shown in Figure 21. As a result of declining natural gas prices and consumption, natural gas expenditures are projected to fall for each income quintile. Overall, average household natural gas expenditures are projected to decline by $1.41 \%$ per year. They are projected to decline at a slightly higher rate (1.50\% per year) for the highest income quintile and a slightly lower rate (1.28\% per year) for the second-income quintile.

Natural gas expenditures are projected to fall at a faster rate in the near term, declining almost twice as fast from 1993 through 2000 as from 2001 through 2015. The difference in the rate of change between these two periods is most significant for the middle income group, which will show a decline of $2.24 \%$ to $0.96 \%$ per year.

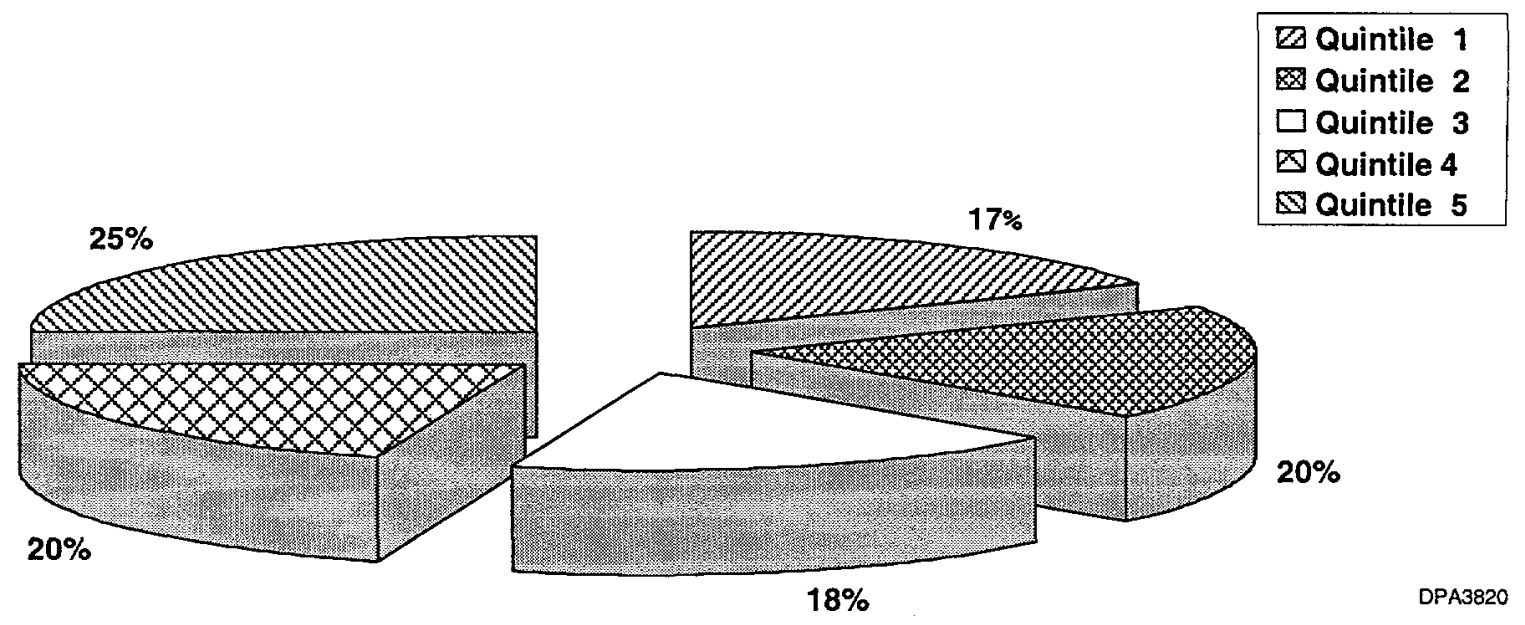

FIGURE 20 Aggregate Natural Gas Consumption Shares by Income Quintile for 1993 and 2015 


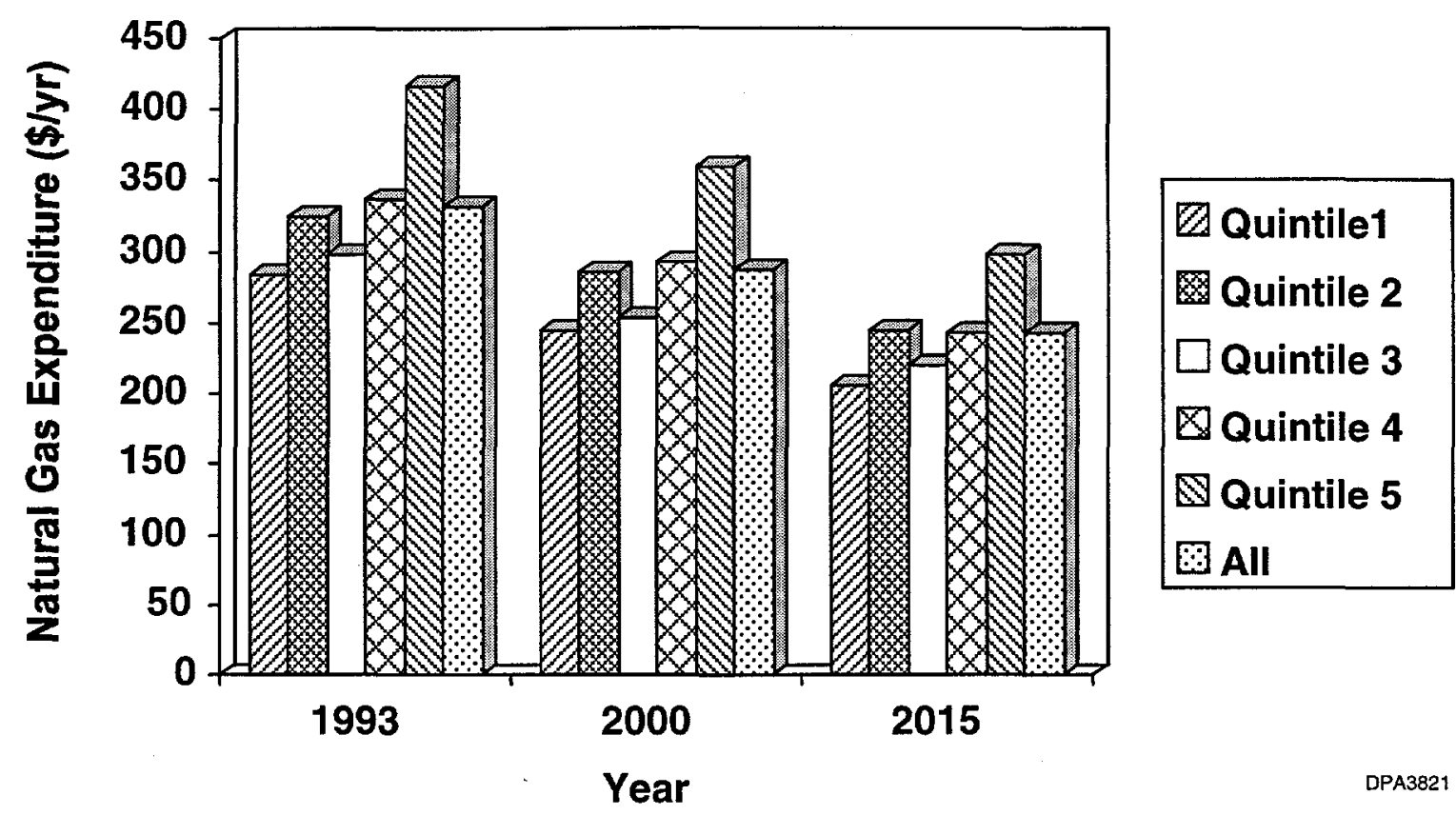

FIGURE 21 Natural Gas Expenditures by Income Quintile for 1993, 2000, and 2015

\subsection{DISTILLATE FUEL CONSUMPTION AND EXPENDITURES}

\subsubsection{Distillate Fuel Consumption}

Forecasts for distillate fuel consumption are shown in Figure 22. The consumption of distillate fuel is projected to fall dramatically (more than $2 \%$ per year) between 1993 and the end of 2015 . Over the entire forecast period, average household use of distillate fuel is projected to fall by almost $40 \%$.

Average distillate fuel consumption is projected to drop for each income group. The decline is expected to be most dramatic for the middle income quintile - about $3.24 \%$ per year. This projected rate of change translates into a decline of more than $50 \%$ in average household distillate fuel consumption over the entire forecast period.

Aggregate distillate fuel consumption shares, by quintile, are shown in Figures 23 and 24 for 1993 and 2015, respectively. During this period, the share of distillate fuel consumption by the middle income quintile falls by 4 percentage points, whereas the shares for the second and fourth income quintiles increase by 2 and 3 percentage points, respectively. The shares for the lowest and highest income quintile groups remain about the same. 


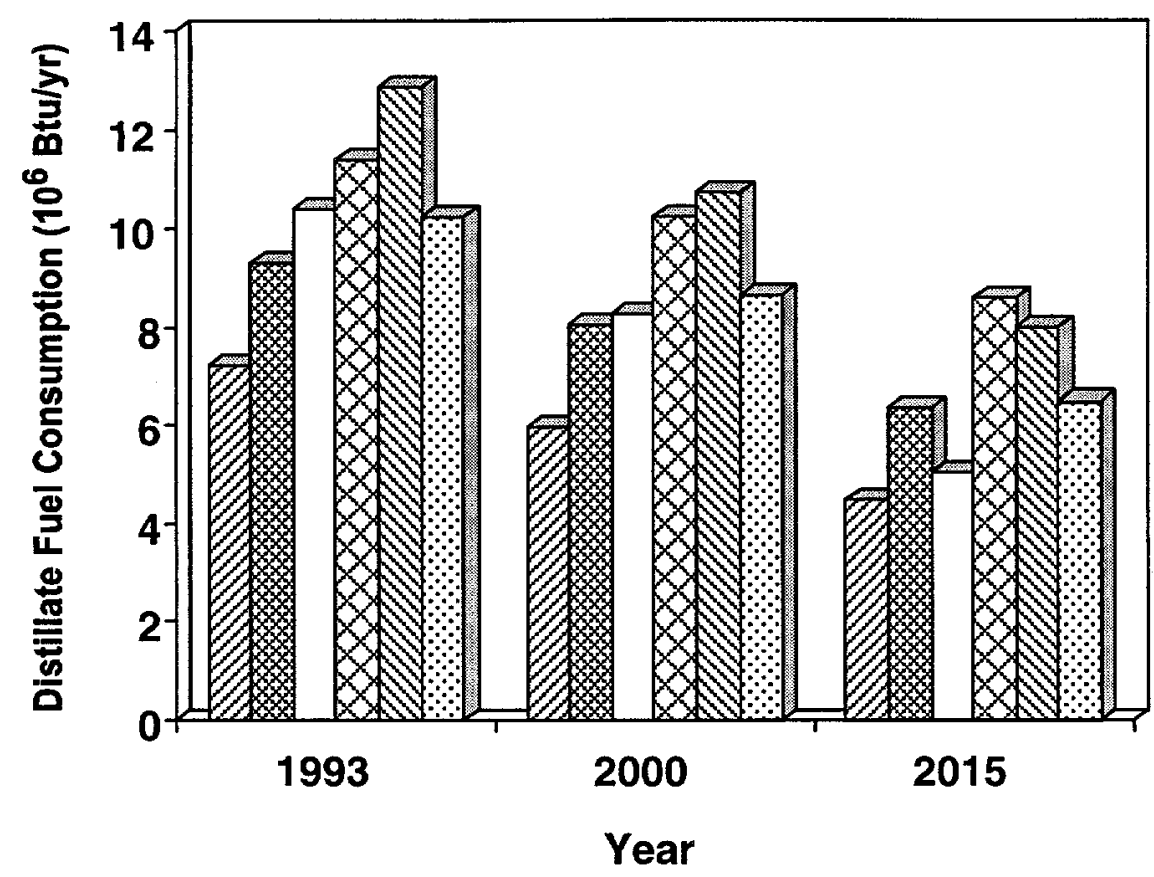

Quintile 1

Quintile 2

$\square$ Quintile 3

Q Quintile 4

Quintile 5

All

FIGURE 22 Distillate Fuel Consumption by Income Quintile for 1993, 2000, and 2015

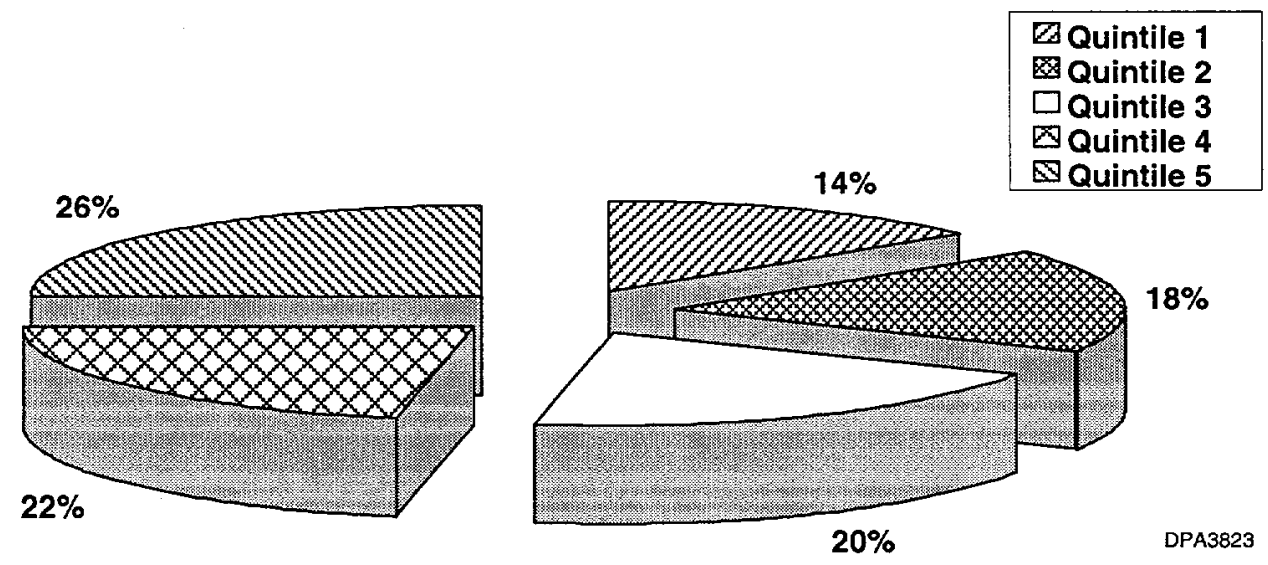

FIGURE 23 Aggregate Distillate Fuel Consumption Shares by Income Quintile for 1993 (Source: DOE 1995a) 

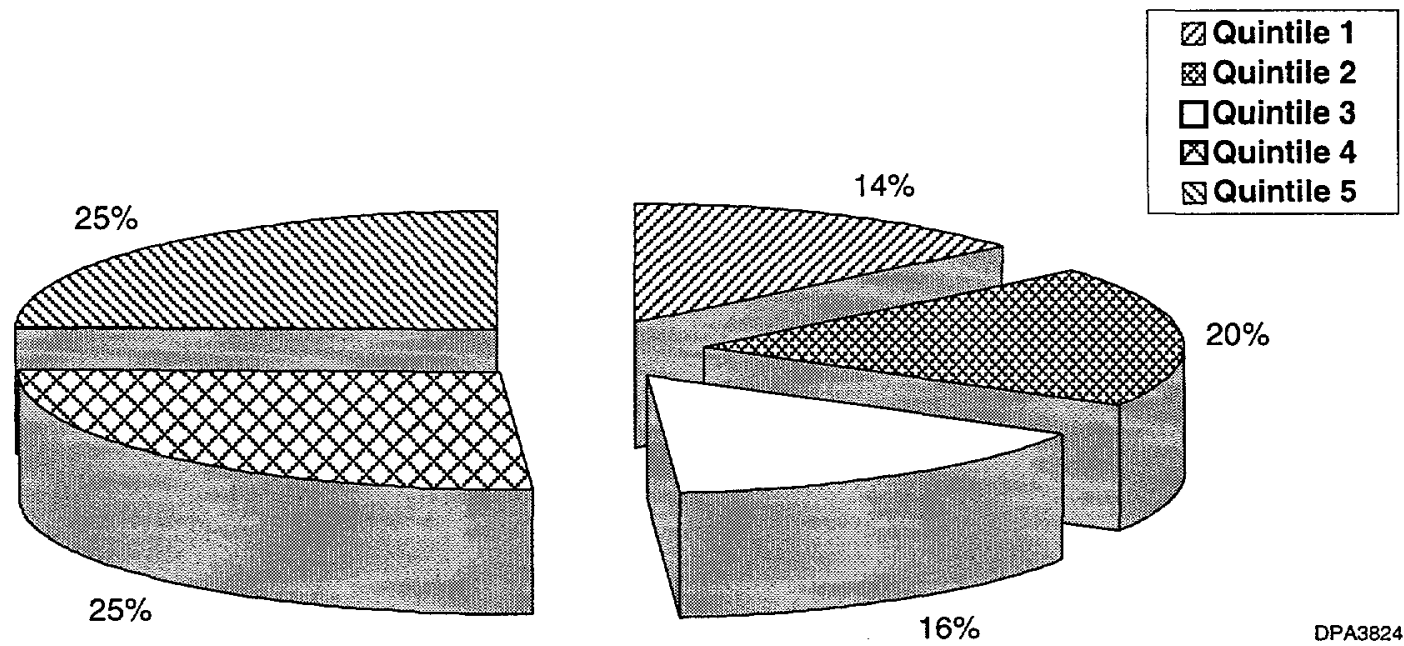

FIGURE 24 Aggregate Distillate Fuel Consumption Shares by Income Quintile for 2015 (Source: DOE 1995a)

\subsubsection{Distillate Fuel Expenditures}

As does distillate fuel consumption, average household distillate fuel expenditures are projected to fall each year during the entire period. Projections show an average decline of $1.76 \%$ per year. For the typical household, this decrease amounts to lower (e.g., by more than 30\%) annual distillate expenditures. By 2015 , the average household is projected to spend less than $\$ 4$ per month (in 1993 dollars) on distillate fuel. Projected distillate fuel expenditures are shown in Figure 25.

While the annual decline in distillate fuel expenditures is substantial for each income quintile, it is projected to be particularly dramatic for the middle income quintile: approximately 1.6 times greater than the overall annual rate. Distillate fuel expenditures for the middle income quintile are projected to decline by nearly 50\% between 1993 and 2015.

\subsection{LPG CONSUMPTION AND EXPENDITURES}

\subsubsection{LPG Consumption}

Moderate changes are projected for average household LPG consumption, with a slight decline projected for each income quintile except for the fourth income quintile. The average annual rate of decline in household LPG consumption is projected to be $0.47 \%$. Between 1993 and 2015 , the average household consumption is projected to decline by approximately $10 \%$ (Figure 26). 


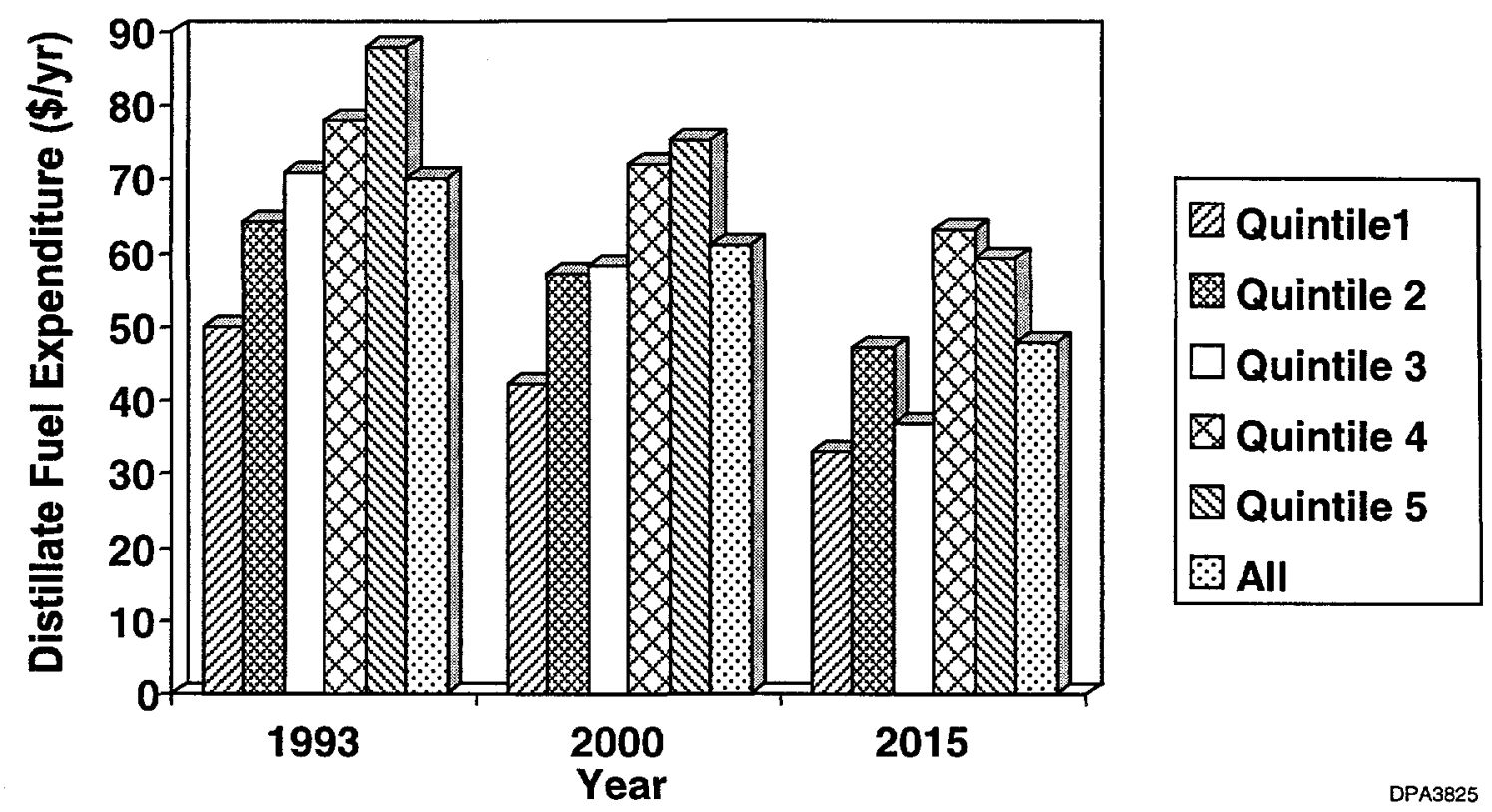

FIGURE 25 Distillate Fuel Expenditures by Income Quintile for 1993, 2000, and 2015
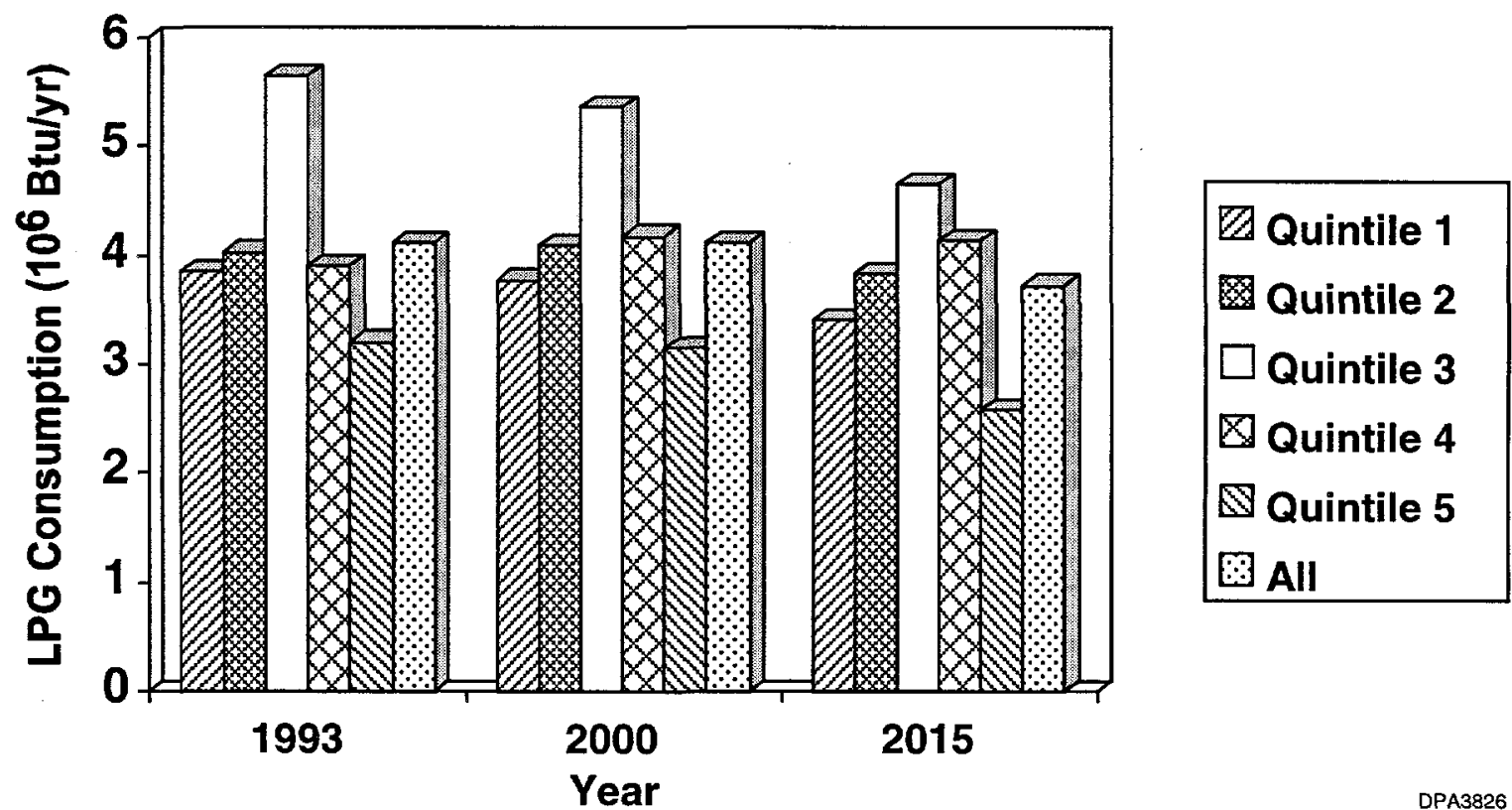

FIGURE 26 LPG Consumption by Income Quintile for 1993, 2000, and 2015 
The change in LPG consumption varies across income groups. It is projected to increase slightly for the fourth income quintile group, whereas projections show a $1 \%$ per year decrease for the highest income quintile. Other income classes fall between these.

Estimated and projected income quintile consumption shares for 1993 and 2015 are shown in Figures 27 and 28, respectively. The consumption shares are projected to increase for the second and fourth income quintiles and decrease for the other three income groups. The increase is projected to be the largest for the fourth income quintile share - from $19 \%$ in 1993 to $22 \%$ in 2015 . The consumption share changes are projected to be smaller for the other income groups.

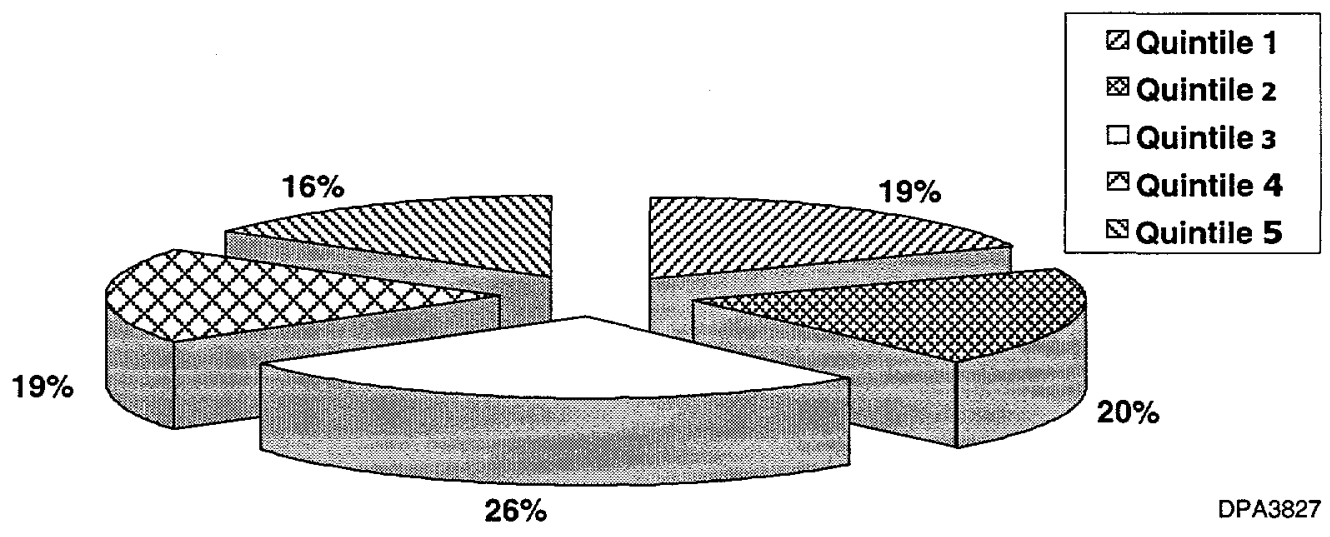

FIGURE 27 Aggregate LPG Consumption Shares by Income Quintile for 1993

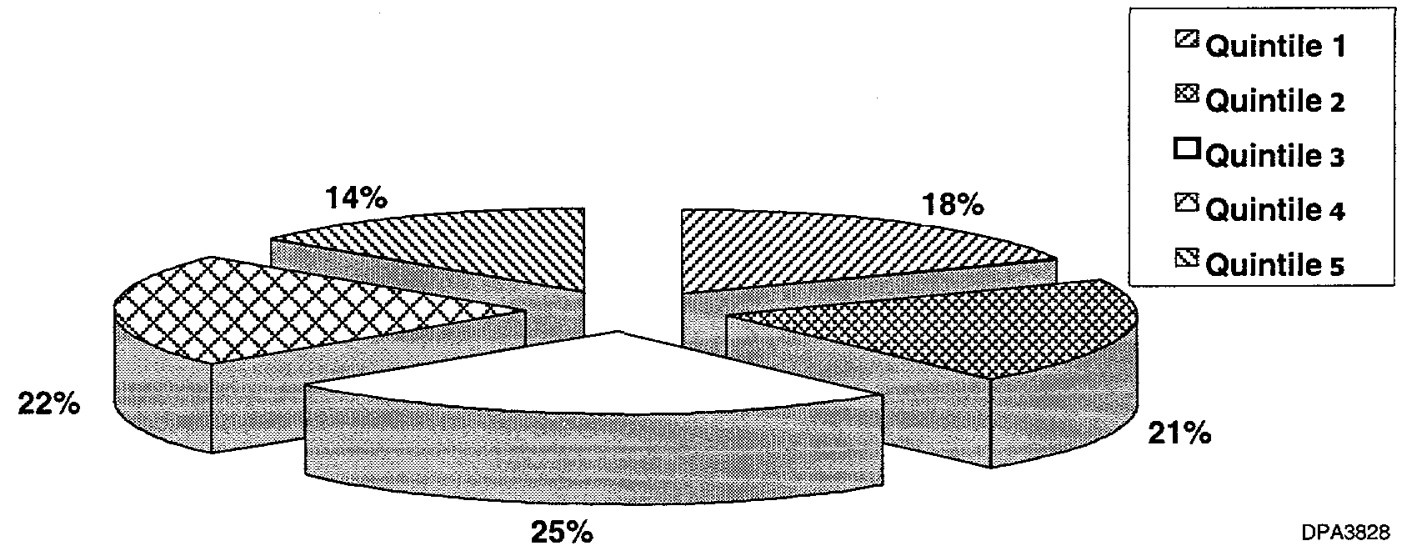

FIGURE 28 Aggregate LPG Consumption Shares by Income Quintile for 2015 


\subsubsection{LPG Expenditures}

Projected LPG expenditures are shown in Figure 29. Overall, changes in LPG expenditures are expected to be minimal between 1993 and 2015 . However, the changes are expected to differ in the near and the long term of that period. The changes generally cancel each other out, and the overall change in LPG expenditures is expected to be minimal. The average annual rate of change in household LPG expenditures, for all households, is projected to decrease by $0.15 \%$.

Near-term forecasts project LPG expenditures to increase at an average annual rate of $0.62 \%$ between 1993 and 2000 . Long-term forecasts project a decline of $0.5 \%$ per year.

The rate of change in LPG expenditures varies significantly across income groups. Projections for average household LPG expenditures between 1993 and 2015 anticipate an increase for the second and fourth income quintiles and a decrease for the other three groups. Expenditures for the fourth income quintile are projected to rise at a substantial $1.67 \%$ per year and then fall to $0.1 \%$ in the forecast period.

Average household LPG expenditures are projected to decline at annual rates of $0.55 \%$ and $0.68 \%$ for the middle and highest income quintiles, respectively. Expenditures are also projected to decline for the middle income quintile - falling at an annual rate of $0.07 \%$ between 1993 and 2000 and $0.77 \%$ between 2000 and 2015. Between the near- and long-term periods, the projected change in the annual rate of expenditures is largest for the highest income group. From

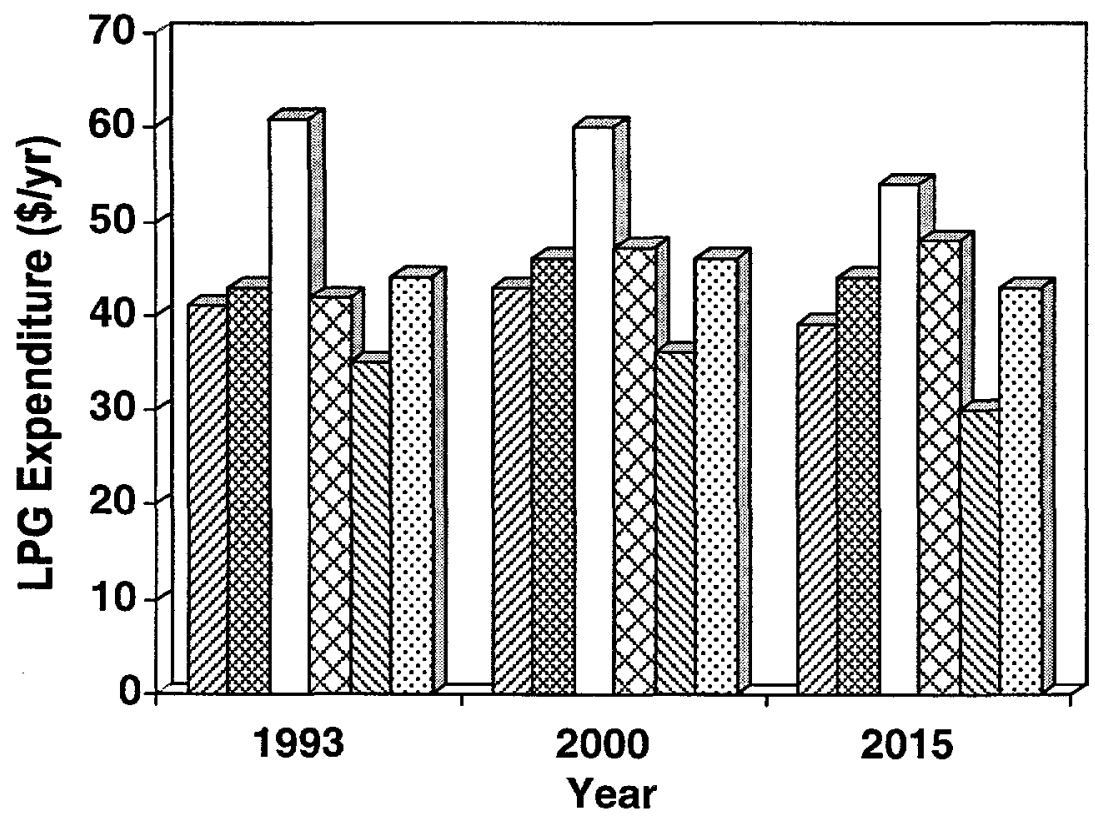

囚Quintile 1 Quintile 2 $\square$ Quintile 3 Q Quintile 4 Quintile 5 All

FIGURE 29 LPG Expenditures by Income Quintile for 1993, 2000, and 2015 
1993 to 2000 , the annual rate of change in LPG expenditures is projected to be $0.46 \%$, whereas from 2000 to 2015 , the annual rate of change is projected to plummet to $-1.2 \%$.

\subsection{HOUSEHOLD ENERGY EXPENDITURES AND INCOME SHARE}

\subsubsection{Energy Expenditures}

Primarily as a result of the projected fall in the cost of natural gas and electricity, household energy expenditures are estimated to decline slightly, but steadily, over the entire forecast period (Figure 30). Expenditures are projected to decline at an average of $0.59 \%$ per year between 1993 and 2000 and $0.4 \%$ between 2000 and 2015 .

The absolute difference in the projected change in household energy expenditures among the income quintiles is not large. The most significant projected fall in expenditures occurs with the lowest and highest income quintiles. Expenditures are projected to decline $0.56 \%$ and $0.57 \%$ per year for the lowest- and highest-income quintiles, respectively. The smallest projected decline in expenditures occurs for the middle and fourth income quintiles; declines are $0.39 \%$ and $0.34 \%$ per year, respectively.

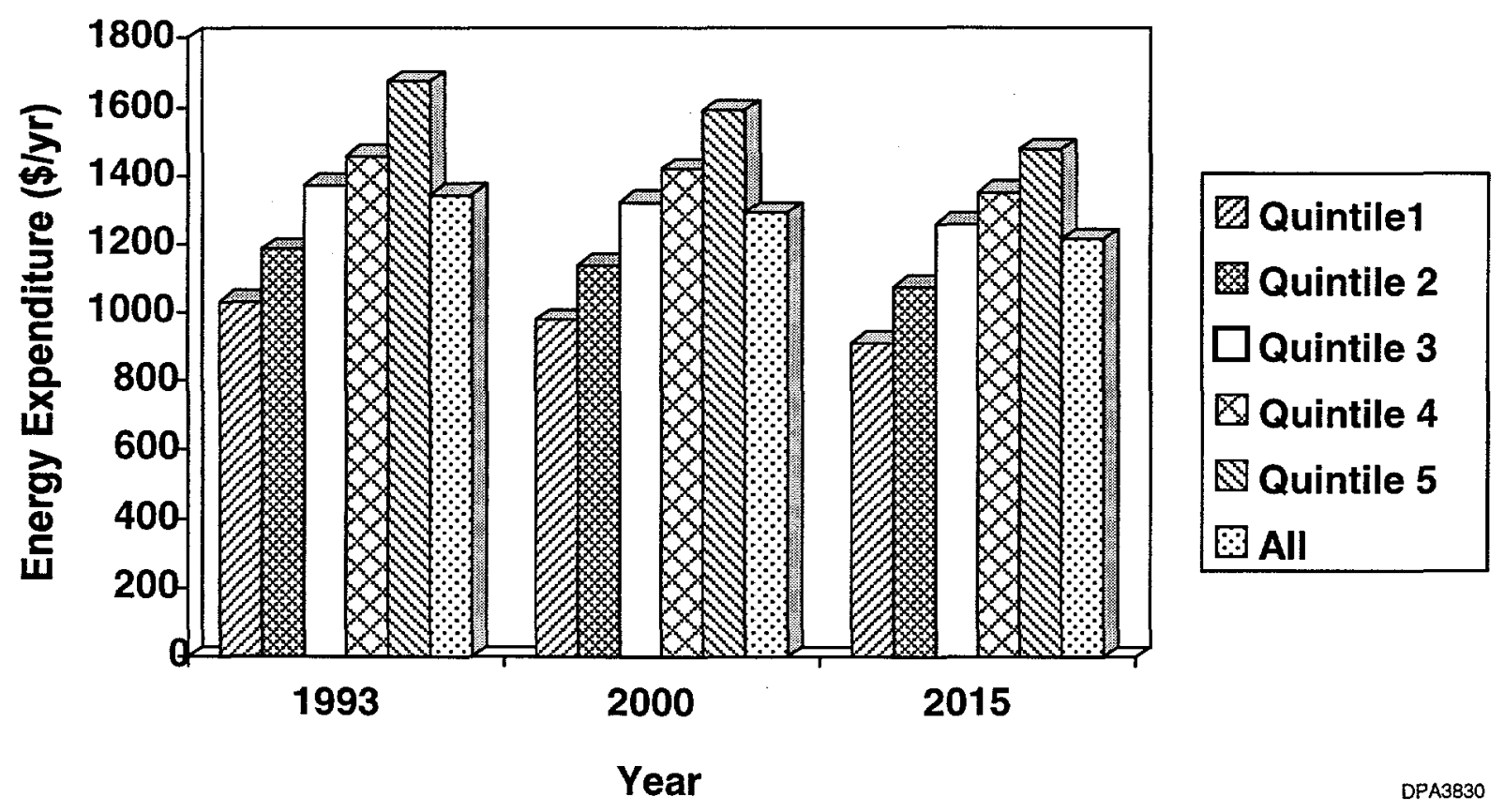

FIGURE 30 Energy Expenditures by Income Quintile for 1993, 2000, and 2015 


\subsubsection{Energy Expenditure Income Share}

As expected, the energy expenditure share of income varies inversely with income, falling as income increases. The lowest income quintile is estimated to spend close to $14 \%$ of household income on residential energy in 1993, whereas the highest income quintile spends only $2 \%$. These shares are projected to improve over the time period examined under the 1997 AEO scenario.

The energy expenditure income share declines throughout the time period under the 1997 AEO energy price and income forecast scenario. Under this scenario, little difference occurs in the relative change in the energy expenditure share of income across income quintiles, as shown in Figure 31 . The energy expenditure share is projected to decline by approximately $30 \%$ for each income group, ranging from a $29 \%$ decline for the fourth income quintile to a $32 \%$ decline for the lowest and highest income quintiles.

\subsubsection{Energy Expenditure Composition}

The residential fuel and electricity shares of energy expenditures for 1993 and 2015 are shown in Figures 32 and 33, respectively. The figures illustrate the relative importance of electricity in a household's energy budget. As income and energy expenditures rise, expenditures

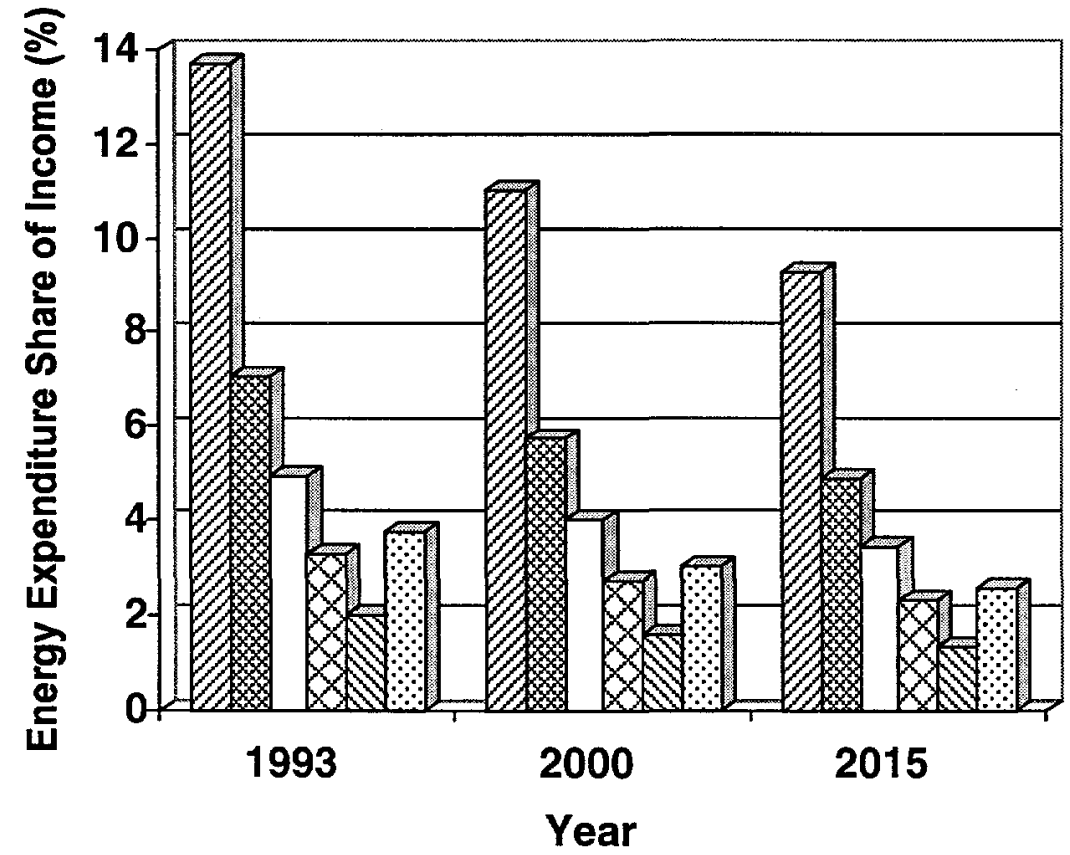

Quintile1 Quintile 2 $\square$ Quintile 3 Quintile 4 Quintile 5 All

FIGURE 31 Energy Expenditure Share of Income by Income Quintile for 1993, 2000, and 2015 


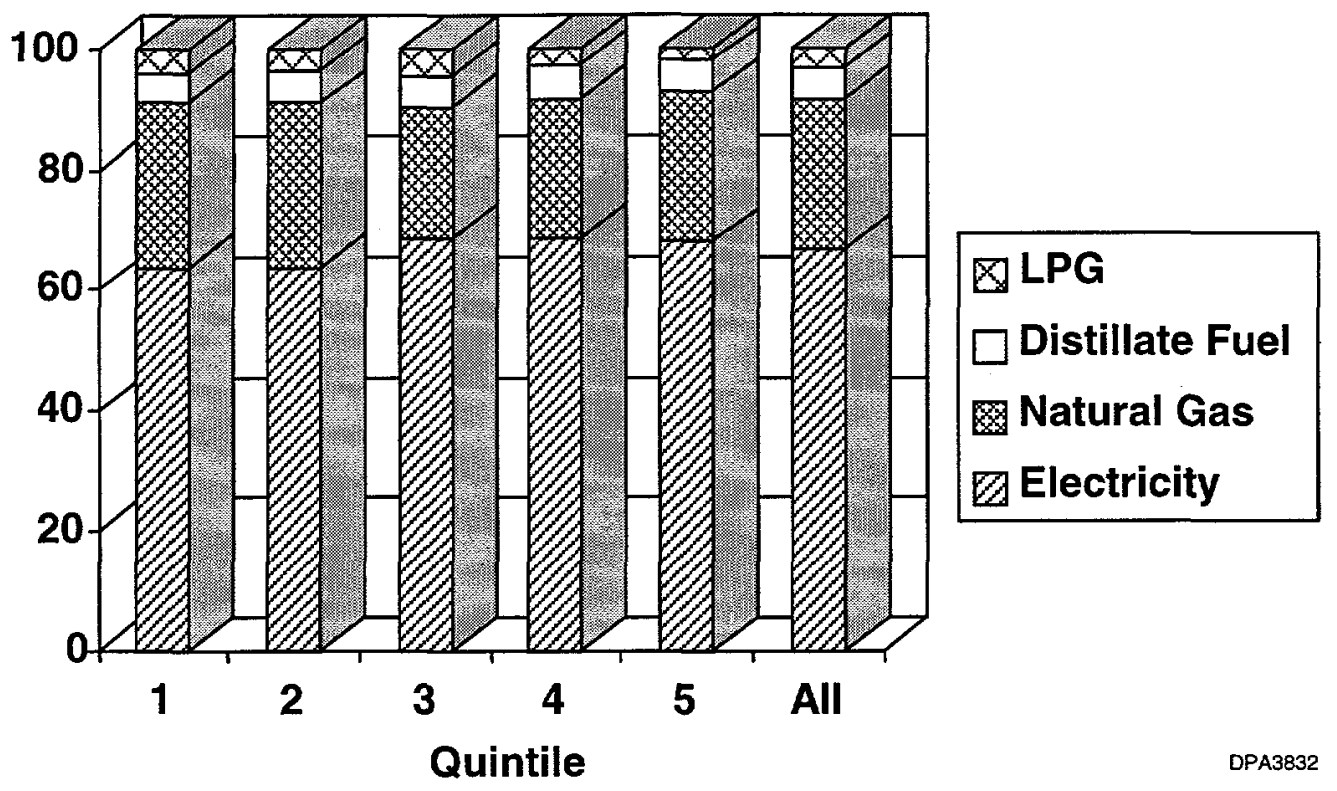

FIGURE 32 Fuel and Electricity Shares of Energy Expenditures by Income Quintile for 1993

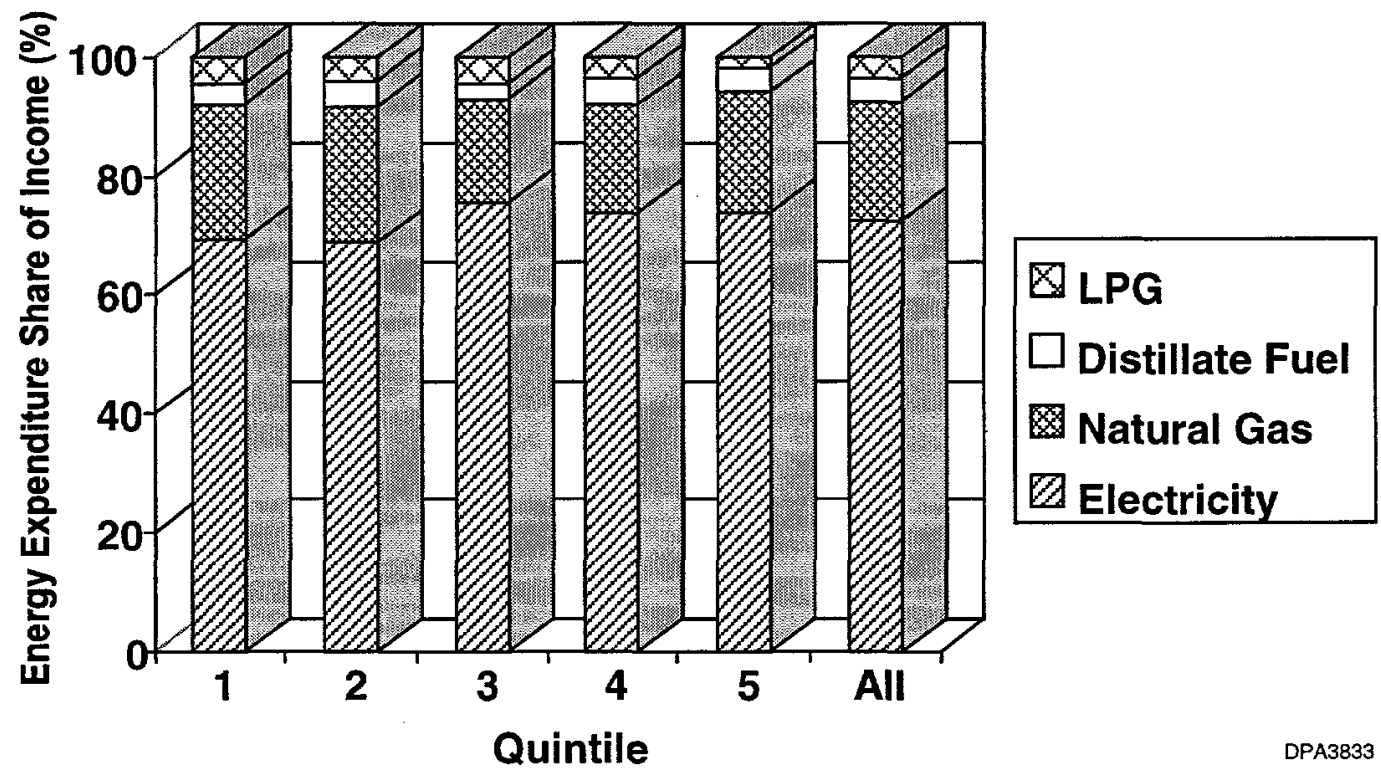

FIGURE 33 Fuel and Electricity Shares of Energy Expenditures by Income Quintile for 2015 
on electricity grow at a disproportionately faster rate, and, as a consequence, electricity's share of total energy expenditures increases. This disproportionate increase occurred in 1993 and is projected to continue until 2015 (the end of the forecast period). In 1993, electricity accounted for approximately $64 \%$ of total residential expenditures for the first and second income quintiles and about $68 \%$ for the third, fourth, and fifth income quintiles.

The electricity share of total residential expenditures grows for each income quintile group. Overall, the share is projected to grow from $67 \%$ to $73 \%$ between 1993 and 2015 . The largest growth is projected for middle income households, increasing from $69 \%$ in 1993 to $75 \%$ in 2015 .

The percentage of total energy expenditures for natural gas falls from $25 \%$ to $20 \%$ between 1993 and 2015. This decline is projected to be particularly large early in the forecast period when natural gas prices are projected to decline rapidly. Without exception, the natural gas energy expenditure share also falls for each income group. The biggest decline occurs for the fourth income quintile.

The most significant declines in energy costs occur for distillate fuel. The share of energy expenditures spent on distillate fuel is projected to fall by more than $25 \%$. The projected decline is particularly significant for those in the middle income quintile; the decline is from $5.2 \%$ in 1993 to $2.9 \%$ in 2015 . Surprisingly, at the other extreme is the fourth income quintile, for which the projected decline is substantially less: from $5.4 \%$ in 1993 to $4.7 \%$ in 2015.

Overall, projections indicate that the LPG energy share will increase slightly between 1993 and 2015. The largest increase is projected to occur in the fourth income quintile, where increases will range from $2.9 \%$ in 1993 to $3.5 \%$ in 2015 . The two lowest income quintiles also show a projected increase in LPG shares, whereas the middle and highest income quintiles are expected to show slight declines in this area. 


\section{CONCLUSIONS}

The composition of household energy consumption is projected to change dramatically under the 1997 AEO forecast scenario. Electricity is projected to become a significantly important component of household energy use over time. With regard to consumption, electricity is the only one of the four major residential energy sources for which consumption is projected to increase for each of the five income groups. Natural gas and distillate fuel consumption are projected to fall for each of the income categories, and overall consumption of LPG per household is projected to decline. Electricity consumption is projected to increase by $14 \%$ between 1993 and 2015, from 35 to 40 million Btu/yr per household. The largest growth in electricity consumption is projected to occur within the third and fourth income groups, by more than $15 \%$ in the third income quintile and $14 \%$ in the fourth income quintile.

Natural gas consumption is projected to decrease slowly during the same period. On the basis of all households, natural gas consumption is projected to decline from 53 to 47 million Btu/yr per household between 1993 and 2015. The average household consumption of this fuel is projected to decline slightly faster for the highest income quintile, from 66 to 57 million Btu/yr per household from 1993 to 2015.

Distillate fuel consumption is projected to fall dramatically for all households over the forecast period, that is, from 10 to 7 million Btu/yr per household from 1993 to 2015, or by almost $40 \%$. Distillate fuel consumption is expected to fall for each income quintile, with the most dramatic decline occurring for the middle income quintile. This group is expected to consume $50 \%$ less distillate fuel, with consumption decreasing from 10 to 5 million Btu/yr per household from 1993 to 2015.

The projected change in LPG consumption varies for the five income quintiles. Overall, LPG consumption is projected to decline from 4.1 to 3.7 million Btu/yr per household from 1993 to 2015 , but it is expected to increase slightly for the fourth income quintile, from 3.9 to 4.1 million Btu/yr per household from 1993 to 2015.

As a result of the declining costs of electricity and natural gas and the more efficient use of energy, real household energy expenditures are projected to decline for each income quintile at an average annual rate of $0.5 \%$. While only slight differences occur in the projected change in energy expenditures among the income quintiles, the composition of total energy expenditures is projected to change dramatically. The major outcome is that electricity will continue to increase in importance. For all households, the electricity share of total energy expenditures is projected to grow from $67 \%$ in 1993 to $73 \%$ in 2015 . The relative change in electricity expenditures is approximately the same across the five income groups.

The growth in the electricity share of energy expenditures comes at the expense of natural gas and distillate fuel. The natural gas expenditure share is projected to fall from $25 \%$ in 1993 to 
$20 \%$ in 2015 ; the share is projected to fall the most for the fourth income quintile: from $23 \%$ in 1993 to $18 \%$ in 2015 . The distillate fuel expenditure share is projected to fall precipitously, by more than $25 \%$ (from 5\% to $4 \%$ between 1993 and 2015). This fall is even more dramatic for the middle income quintile: down from 5\% in 1993 to $3 \%$ in 2015.

It is projected that the overall energy expenditure share of income will drop from $3.7 \%$ in 1993 to $2.6 \%$ in 2015 . Under the 1997 AEO scenario, the energy expenditure share of household income is projected to fall from $13.7 \%$ to $9.3 \%$ for the lowest income quintile. 


\section{REFERENCES}

DOE: See U.S. Department of Energy

Poyer, D.A., and M. Williams, 1993, "Residential Energy Demand: Additional Empirical Evidence by Minority Household Type," Energy Economics 15(2):93-100.

Poyer, D.A., L. Henderson, and A.P.S. Teotia, 1997, "Residential Energy Consumption across Different Population Groups: Comparative Analysis for Latino and Non-Latino Households in USA," Energy Economics 19:445-463.

U.S. Department of Energy, 1995a, Residential Energy Consumption Survey 1993, public-use data tape, Energy Information Administration, Washington, D.C.

U.S. Department of Energy, 1995b, Household Energy and Expenditures 1993, DOE/EIA-0321 (93), Energy Information Administration, Washington, D.C.

U.S. Department of Energy, 1996a, Annual Energy Outlook 1997, DOE/EIA-0383 (97), Energy Information Administration, Washington, D.C.

U.S. Department of Energy, 1996b, 1997 AEO/NEMS Lotus 1-2-3 Data Sheet, Energy Information Administration, Washington, D.C. 